\title{
MeCP2 and Chromatin Compartmentalization
}

\author{
Annika Schmidt ${ }^{\dagger}$, Hui Zhang ${ }^{\dagger}$ and M. Cristina Cardoso $*$ (]) \\ Department of Biology, Technical University of Darmstadt, 64287 Darmstadt, Germany; \\ annika.schmidt.mail@gmail.com (A.S.); zhanghui20139@gmail.com (H.Z.) \\ * Correspondence: cardoso@bio.tu-darmstadt.de; Tel.: +49-6151-16-21882; Fax: +49-6151-16-21880 \\ + They are first authors.
}

Received: 3 March 2020; Accepted: 1 April 2020; Published: 3 April 2020

\begin{abstract}
Methyl-CpG binding protein 2 (MeCP2) is a multifunctional epigenetic reader playing a role in transcriptional regulation and chromatin structure, which was linked to Rett syndrome in humans. Here, we focus on its isoforms and functional domains, interactions, modifications and mutations found in Rett patients. Finally, we address how these properties regulate and mediate the ability of $\mathrm{MeCP} 2$ to orchestrate chromatin compartmentalization and higher order genome architecture.
\end{abstract}

Keywords: DNA modifications; DNA methylation readers; higher order chromatin structure; heterochromatin; MeCP2; Rett syndrome

\section{Introduction}

In humans, the two meter long genomic DNA is hierarchically folded to fit inside the membrane-bound micrometer-scale cell nucleus. Individual chromosomes occupy distinct subnuclear territories. The chromosome territories have been proposed to be further subdivided into two mutually excluded compartments called ' $\mathrm{A}$ ' (active) and 'B' (inactive) with distinct accessibilities. Each compartment was reported to consist of multiple topologically associating domains (TADs) (reviewed in [1]). Within TADs, DNA/chromatin looping was predicted to promote higher DNA interaction frequencies among DNA sites located far apart within the linear DNA molecule (reviewed in [1]).

Epigenetic chromatin modifications, including DNA and histone modifications, were shown to control genome accessibility [2] and, thus, the spatial-temporal gene expression without changing the nucleotide sequence. DNA methylation, established by DNA methyltransferases, blocks the access of multiple factors to DNA, thus creating repressive regions. This DNA modification is read by methyl-CpG binding domain (MBD) protein family, which in addition recruit specific chromatin modifiers (reviewed in [3]). Methyl-CpG binding protein 2 (MeCP2) was the first member of the MBD family to be identified [4] and the most extensively studied one. Hereafter, we will focus on MeCP2 isoforms, domains, interactions, modifications and mutations before moving to its role in higher order chromatin organization.

\section{MeCP2 Interactions, Modifications and Mutations}

\subsection{MeCP2 Isoforms and Domains}

The $\mathrm{MeCP} 2$ gene is highly conserved in Euteleostomi (bony vertebrates) and in humans is located on the $\mathrm{X}$ chromosome. Mutations in the $\mathrm{MeCP} 2$ gene were linked to the human neurological disorder Rett syndrome (RTT) [5]. The MeCP2 protein has two isoforms (MeCP2 e1 (exon 1) and MeCP2 e2 (exon 2)) with different amino termini due to alternative splicing and different translational start sites. The two isoforms of MeCP2 are abundantly expressed in the central nervous system, but with different expression levels and distributions in developing and post-natal mouse brains. MeCP2 e1 is 
the predominant isoform in brain and has an earlier expression onset than MeCP2 e2 [6]. The two isoforms are commonly considered as functionally equivalent, yet recent evidence shows that MeCP2 e1 plays a role in neuronal maturation [7] and is more relevant for RTT [8-10]. In view of the fact that MeCP2 e2 isoform was the first to be known and a much larger body of literature pertains to this isoform, we will, throughout, use amino acid coordinates from MeCP2 e2 isoform.

Both variants include two functionally characterized domains: the methyl-CpG binding domain (MBD) and the transcriptional repression domain (TRD). The MBD specifically recognizes and binds 5-methylcytosine $(5 \mathrm{mC})$, while the TRD was found to bind multiple transcriptional repressors, thus silencing gene expression [11-16]. However, the TRD was also shown to bind to multiple transcriptional activators and activate gene expression [17-19]. More recently, the TRD has been narrowed down to the N-CoR/SMRT interacting domain (NID) [20]. A summary of the best characterized domains of $\mathrm{MeCP} 2$ is shown in Figure 1. The DNA binding properties of the different domains and the mechanism of DNA binding will be addressed in the next section.

\subsection{MeCP2 DNA Binding}

Early studies on $\mathrm{MeCP} 2$ characterized it as a protein being capable to bind to a single, symmetrically methylated CpG pair via the MBD domain spanning amino acids 89 - 162 and thereby overlapping approximately twelve base pairs of DNA [4,21,22]. Later studies indicated that the N-terminal domain (NTD) enhanced DNA binding affinity via the MBD [23], while the intervening domain (ID), TRD and C-terminal domain (CTD) alpha showed methylation-independent DNA binding capabilities and CTD beta was proposed to bind to chromatin, but not to naked DNA $[23,24]$. Furthermore, three AT-hook-like domains were identified within the ID, TRD and CTD alpha domains (AT-hook 1, aa 184-195; AT-hook 2, aa 264-273; AT-hook 3, aa 341-364). The AT-hook motif is a short motif binding to the minor groove of AT-rich DNA via the core consensus amino acid sequence RGRP [25]. These methylation-independent DNA binding capabilities allow MeCP2 to bind to different sites on the DNA at the same time, thus, possibly contributing to genome-wide chromatin organization. With the exception of the MBD, MeCP2 was shown to be mostly an intrinsically disordered protein. Upon binding to DNA, though, increased secondary structure in ID and TRD were observed [23]. The MBD is the only domain showing structurally conserved motifs, as it contains four beta-sheets and one alpha-helix building up a wedge shape with a beta-sheet face presenting positively charged amino acids for interaction with the DNA as determined by nuclear magnetic resonance analysis [26]. Accordingly, this domain showed only minor conformational changes as a result of DNA binding [23,26]. The subsequent crystal structure of the MBD bound to the Bdnf gene promotor revealed that MBD mCpG interaction might involve five water molecules, leaving only three amino acids with direct contact to the DNA: D121, R111 and R133 [27]. In line with this study, these amino acids were found mutated in RTT and with significantly reduced MeCP2 DNA binding [27-29].

Dynamic structural analysis of MeCP2 using H/DX-MS, led to the proposal that the intrinsically disordered MeCP2 samples multiple conformational states, also during non-specific interaction with the DNA [30].

Using genome wide chromatin immunoprecipitation-sequencing (ChIP-seq) analysis, MeCP2 was found to bind globally across the genome tracking $\mathrm{mCpG}$ density [31]. Furthermore, in purified nuclei from mouse brain MeCP2 was shown to be expressed at near histone octamer levels [31]. These findings suggest that MeCP2 binds globally across the genome reducing transcriptional noise. 
Nevertheless, MeCP2 was also described to bind to actively transcribed unmethylated DNA in vivo [17,32] with only a minor portion of MeCP2-bound promoters being highly methylated [32]. A possible explanation would be that MeCP2 folds upon binding to DNA and scans the DNA for suitable binding sites making use for this of its non-specific DNA binding sites [23,33]. Thus, it would only bind non-specifically to active genes to scan the DNA for $\mathrm{mCpG}$ binding sites.

Recently, MeCP2 was reported to bind not only mCpG but also mCpApC [34]. The patterns of $\mathrm{mCpApC}$ differ between neuronal cell types and may, thus, contribute to cell type specific effects of $\mathrm{MeCP} 2[35,36]$.

In addition to binding DNA and methylated cytosines, MeCP2 was proposed to bind to 5-hydroxymethylcytosine $(5 \mathrm{hmC})$ in mouse brain [37] and embryonic stem cells [38]. 5hmC is an oxidation product of $5 \mathrm{mC}$ and can be further oxidized to 5 -formylcytosine $(5 \mathrm{fC})$ and 5 -carboxylcytosine $(5 \mathrm{caC})$ by TET (ten-eleven-translocation) proteins, which might enable active DNA demethylation by different pathways (reviewed in [39]). In addition, $5 \mathrm{hmC}$ levels were reported to be differentially distributed between different tissues, much lower than $5 \mathrm{mC}$ levels and associated to actively expressed and developmentally regulated genes [40]. Nevertheless, these findings are highly debated, as the results are tissue and cell type dependent $[37,38]$, the recognition mechanism of $5 \mathrm{hmC}$ by MeCP2 is unclear and other studies hint to a binding affinity similar to binding unmethylated DNA [41-43].

A more indirect way of MeCP2 to repress transcription by DNA binding is the protection of $\mathrm{MeCP} 2$ bound $5 \mathrm{mC}$ against oxidation to $5 \mathrm{hmC}$ by TET enzymes by restricting their access to the methylated cytosine [44]. This was proposed to contribute to restricting transcriptional noise [31] and, in particular, repressing tandem repeat DNA expression [44] and L1 retrotransposition [45-47]. TET-mediated L1 activation was shown to be prevented by binding of MeCP2 to 5mC [47].

Summarizing, methylation-specific and unspecific MeCP2 DNA binding are both essential for its function in transcriptional repression and chromatin organization, and its multifunctional domain structure allows the protein to simultaneously bind to DNA and interact with other proteins, which will be described next.

\subsection{MeCP2 Protein-Protein Interactions}

Interactions of $\mathrm{MeCP} 2$ with several proteins mediate and regulate its multiple functions in transcriptional regulation, chromatin organization and RNA splicing. An overview of interacting proteins, the interacting $\mathrm{MeCP} 2$ regions and the function of these interactions is presented in Figure 1 and Table 1.

One major mechanism by which $\mathrm{MeCP} 2$ represses transcription is by recruiting corepressor complexes to methylated DNA. One such complex contains mSin3A and histone deacetylases (HDACs), suggesting that transcriptional repression may in part rely on histone deacetylation [11,12], e.g., by removing active chromatin marks. mSin3A was shown to be the direct $\mathrm{MeCP} 2$ binding partner, whereas HDACs showed a weaker binding affinity to $\mathrm{MeCP} 2$ and, thus, might bind via mSin3A [11]. Another corepressor complex reported to interact with MeCP2 is the NCoR/SMRT interacting with a small region within the TRD domain, which was thus called NID. The data suggested that MeCP2 recruited NCoR/SMRT to methylated DNA and that this MeCP2 bridge function is disturbed in RTT [20]. Interestingly, binding of Sin3A was not disrupted by NID mutations [20].

In addition to transcriptional repression, MeCP2 might also work as an activator, as it was found associated with the transcriptional activator CREB1 (cyclic AMP-responsive element-binding protein 1) at the promoter of an activated gene [17]. In gene expression analysis from mouse hypothalami, the gain of MeCP2 was shown to result in more transcriptional activation than repression, whereas MeCP2 loss lead to reverse effects [17]. These results are in line with a previous study, where only a minor portion of $\mathrm{MeCP} 2$ was found bound to methylated $\mathrm{CpGs}$, but $63 \%$ of $\mathrm{MeCP} 2$ were bound to actively expressed promoters [32]. In other studies though, MeCP2 was found to track methylated CpGs genome wide [31], as described above. 
As transcriptional activity is influenced by chromatin organization, these MeCP2 functions can hardly be separated. By interacting with histone methyltransferase acting on histone $\mathrm{H} 3$ lysine 9, MeCP2 was reported to target histone methylation to methylated regions on the DNA [48]. As mentioned above, $\mathrm{MeCP} 2$ transcriptional repression involves recruitment of histone deacetylases and deacetylation of histones is likely followed by histone methylation [48], thus switching chromatin from an active to a repressive state. Histone methylation may result in recruitment of other proteins like heterochromatin protein 1 (HP1), thus reinforcing the repressed chromatin state [49,50]. MeCP2 and HP1 were shown to interact [51] and both were reported to associate with SUV39H1 (suppressor of variegation 3-9 homolog 1) histone methyltransferase [13,52], which methylates histone $\mathrm{H} 3$ lysine 9. In addition, MeCP2 might be involved in regulation of maintenance DNA methylation by DNMT1 (DNA methyltransferase 1), as the interaction of both proteins was also described [53]. DNMT1 interacts with HDAC1 and 2 [54,55], and was shown to replace the mSin3A-HDAC complex upon MeCP2 binding [53].

Another mechanism by which MeCP2 modulates chromatin architecture could be oligomerization. In that regard, $\mathrm{MeCP} 2$ was shown to associate with itself and the methyl $\mathrm{CpG}$ binding domain protein 2 (MBD2) [56]. Furthermore, MeCP2 associates with the chromatin remodeling protein ATRX (alpha-thalassemia/cognitive disability syndrome X-linked). Analysis of MeCP2 null mouse brains showed delocalization of ATRX from heterochromatic foci, suggesting a MeCP2-dependent ATRX targeting to heterochromatic regions in mature neurons [57]. As the MeCP2 mediated ATRX targeting to heterochromatin took place only in mature neurons where MeCP2 is very abundant [57], this underscores the relevance of $\mathrm{MeCP} 2$ level for its function.

$\mathrm{MeCP} 2$ might also play a functional role in RNA splicing, as it binds to WW domains of the splicing factors FBP (formin-binding protein) 11 and HYPC (Huntington yeast partner C) via a proline rich domain in the MeCP2 C-terminus [58,59]. Genotype-phenotype studies on RTT frameshift mutations support the hypothesis that disruption of the proline-rich region in the MeCP2 C-terminus, thus abolishing its binding to FBP11 and HYPC, contributes to Rett phenotype [59]. In addition, association of MeCP2 with the $\mathrm{Y}$ box-binding protein 1 (YB-1), a conserved DNA and RNA binding protein [60], promotes exon inclusion in YB-1 responsive CD44-splicing reporter assays [60]. This leads to the proposal that misregulation of transcription as well as splicing might contribute to RTT [60].

Although several MeCP2 interaction partners were identified so far, the whole network of protein-protein interactions, their interplay and the entire composition of $\mathrm{MeCP} 2$ transcription silencing compartments require further investigation. Importantly, MeCP2 DNA binding and protein-protein interactions need to be studied in the context of post-translational modifications as these can abolish or enhance DNA and protein binding, thus, ultimately influencing chromatin organization. 


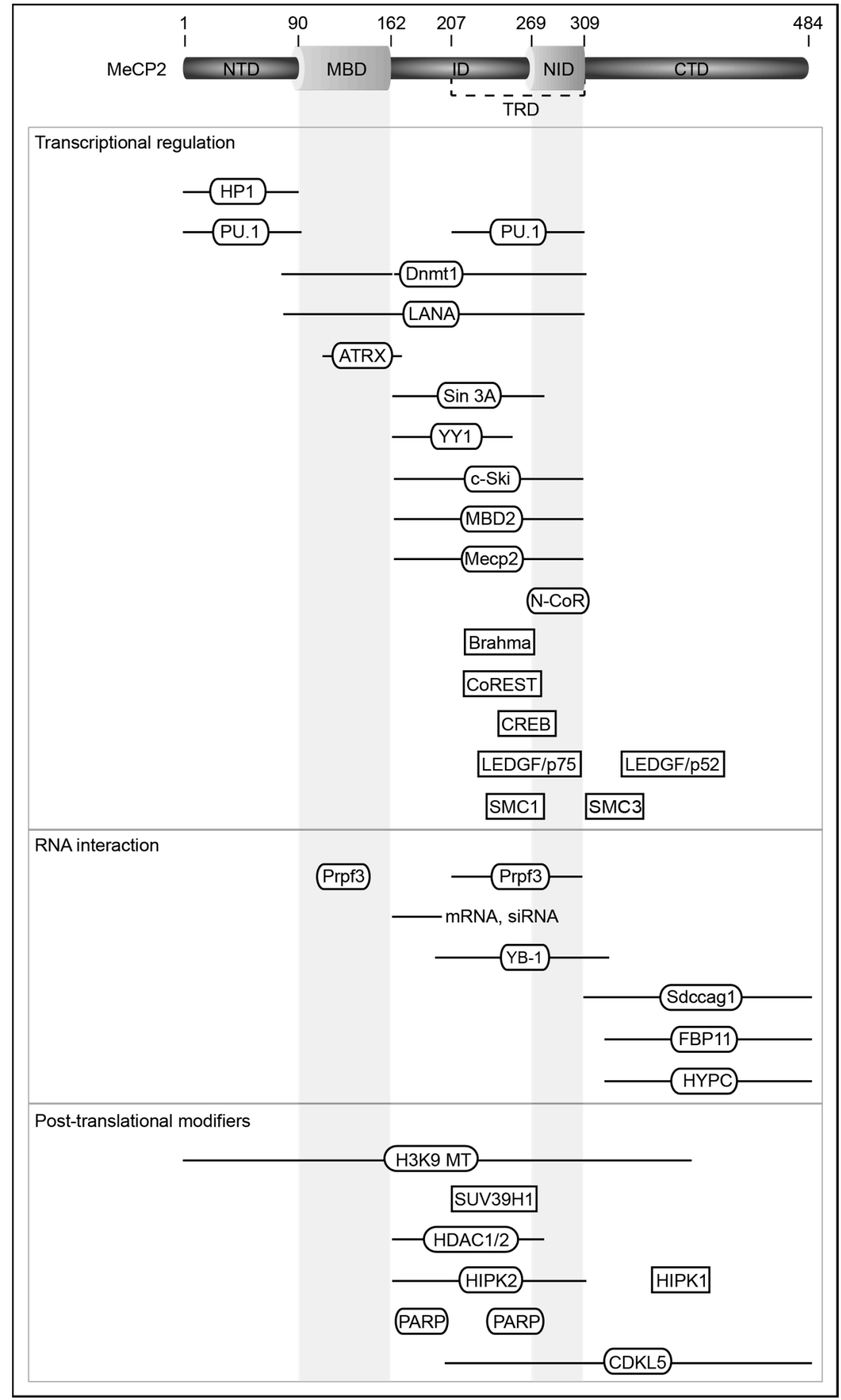

Figure 1. Overview of MeCP2 interaction partners. MeCP2 interaction partners, group by main function and ordered by where they interact within MeCP2, if known. References are given in Table 1. Rectangles indicate proteins with no mapped interaction region within MeCP2. NTD: N-terminal domain; MBD: methyl binding domain; ID: intervening domain; NID: N-CoR interacting domain; CTD: C-terminal domain; TRD: transcriptional repression domain. Amino acid labeling according to mouse $\mathrm{MeCP} 2$ isoform e2. Protein domain structure generated using DOG 1.0 software [61]. 
Table 1. MeCP2 interaction partners and function upon interaction.

\begin{tabular}{|c|c|c|c|}
\hline & Interactor & MeCP2 Function Upon Interaction & References \\
\hline \multirow{16}{*}{$\begin{array}{l}\text { Transcriptional } \\
\text { repression }\end{array}$} & HP.1 & repression, formation of subcellular silencing compartments & Agarwal et al., 2007 [51] \\
\hline & PU.1 & formation of repression complex, possibly recruitment of mSin3A-HDAC & Suzuki et al., 2003 [15] \\
\hline & Dnmt1 & association with $\mathrm{MeCP} 2$ contributes to maintenance methylation & Kimura \& Shiota 2003 [53] \\
\hline & LANA & $\begin{array}{l}\text { MeCP2 directs LANA to chromocenters, might contribute to } \\
\text { LANA-mediated repression }\end{array}$ & Matsumura et al., 2010, Krithivas et al., 2002 [62,63] \\
\hline & ATRX & $\begin{array}{l}\text { targeting to heterochromatic regions in mature neurons, silencing of } \\
\text { imprinted genes; possibly control of nucleosome positioning }\end{array}$ & $\begin{array}{c}\text { Nan et al., 2007, } \\
\text { Kernohan et al., } 2010[57,64]\end{array}$ \\
\hline & $\operatorname{Sin} 3 \mathrm{~A}$ & transcriptional repression, corepression complex with $\mathrm{HDAC}$ and $\mathrm{MeCP} 2$ & $\begin{array}{c}\text { Nan et al., 1998, } \\
\text { Jones et al., } 1998[11,12]\end{array}$ \\
\hline & YY1 & cooperation in repression & Forlani et al., 2010 [16] \\
\hline & c-Ski & transcriptional repression & Kokura et al., 2001 [14] \\
\hline & MBD2 & heterointeractions, might increase heterochromatin clustering & Becker et al., 2013 [56] \\
\hline & $\mathrm{MeCP} 2$ & homointeractions, might increase heterochromatin clustering & Becker et al., 2013 [56] \\
\hline & $\mathrm{N}-\mathrm{CoR}$ & recruitment of N-CoR/SMRT to methylated DNA, bridge function of MeCP2 & $\begin{array}{l}\text { Kokura et al., 2001, } \\
\text { Lyst et al., } 2013[14,20]\end{array}$ \\
\hline & Brahma & transcriptional repression & Harikrishnan et al., 2005 [65] \\
\hline & CoREST & $\begin{array}{l}\text { transcriptional repression possibly involving REST, CoREST, MeCP2, } \\
\text { SUV39H1 and HP1 }\end{array}$ & Lunyak et al., 2002 [13] \\
\hline & CREB & transcriptional activation & Chahrour et al., 2008 [17] \\
\hline & LEDGF/p75 & might differentially influence gene activation & Leoh et al., 2012 [18] \\
\hline & SMC1, SMC3 & interaction with $\mathrm{MeCP} 2, \mathrm{ATRX}$, might promote repression by loop formation & Kernohan et al., 2010, Gonzales et al., $2012[19,64]$ \\
\hline
\end{tabular}


Table 1. Cont.

\begin{tabular}{|c|c|c|c|}
\hline & Interactor & MeCP2 Function Upon Interaction & References \\
\hline \multirow{6}{*}{ RNA interaction } & Prpf3 & RNA binding, possibly involved in splicing & Long et al., 2011 [66] \\
\hline & mRNA, siRNA & not known & Jeffrey et al., 2004 [67] \\
\hline & YB-1 & RNA-dependent complex, regulation of splicing & Young et al., 2005 [60] \\
\hline & Sdccag1 & not known & Long et al., 2011 [66] \\
\hline & FBP11 & not known & $\begin{array}{l}\text { Buschdorf \& Stratling 2004, Bedford et al., } 1997 \\
\qquad[58,59]\end{array}$ \\
\hline & HYPC & not known & Buschdorf \& Stratling 2004 [59] \\
\hline \multirow{6}{*}{$\begin{array}{l}\text { post-translational } \\
\text { modifiers }\end{array}$} & H3К9 MT & targeting of histone methylation to methylated DNA & $\begin{array}{c}\text { Fuks et al., 2003, } \\
\text { Lunyak et al., } 2002[13,48]\end{array}$ \\
\hline & SUV39H1 & $\begin{array}{l}\text { association with MeCP2 might contribute to silencing by methylation of } \\
\qquad \mathrm{H} 3 \mathrm{~K} 9 \text {, creating HP1 binding sites }\end{array}$ & Lunyak et al., 2002 [13] \\
\hline & HDAC $1 / 2$ & histone deacetylases form corepression complex with $\mathrm{MeCP} 2$ and Sin3A & $\begin{array}{l}\text { Nan et al., 1998, } \\
\text { Jones et al., } 1998[11,12]\end{array}$ \\
\hline & HIPK2, HIPK1 & kinases might phosphorylate MeCP2 on S80 and S216 & Bracaglia et al., 2009, Lombardi et al., $2017[68,69]$ \\
\hline & PARP & poly(ADP-ribosyl)ation reduces $\mathrm{MeCP} 2$ heterochromatin clustering ability & Becker et al., 2016 [70] \\
\hline & CDKL5 & $\begin{array}{l}\text { association in vitro, phosphorylation of MeCP2 by CDKL5 unclear } \\
\text { (opposing results in the two publications) }\end{array}$ & $\begin{array}{c}\text { Mari et al., 2005, } \\
\text { Lin et al., } 2005 \text { [71,72] }\end{array}$ \\
\hline
\end{tabular}




\subsection{MeCP2 Post-Translational Modifications}

Recently, several MeCP2 post-translational modifications (PTMs) were reported, mostly in large scale proteomic studies focusing on mapping one specific PTM in the whole proteome. In Table 2, experimentally determined MeCP2 modifications are summarized, together with the species in which they were identified, the methods used for identification along with references. A more detailed list can be found on PhosphoSitePlus.org [73], including additional sites only available as curated datasets. 
Table 2. Summary of MeCP2 post-translational modifications.

\begin{tabular}{|c|c|c|c|c|c|}
\hline & Residue* $^{*}$ & Modification & Species & MS/Other Methods & References $^{* *}$ \\
\hline \multirow{9}{*}{ NTD } & K12 & ubi & human & $\mathrm{x} /-$ & Gonzales et al., 2012 [19] \\
\hline & S13 & phos & human, mouse & $\mathrm{x} /-$ & Gonzales et al., 2012, Humphrey et al., 2013, Shiromizu et al., 2013 [19,74,75] \\
\hline & S53 & phos & human & $\mathrm{x} /-$ & Shiromizu et al., 2013, Bian et al., 2014, Sharma et al., 2014 [75-77] \\
\hline & S68 & phos & mouse & $\mathrm{x} /-$ & Huttlin et al., 2010 [78] \\
\hline & S70 & phos & mouse, human & $\mathrm{x} /-$ & Huttlin et al., 2010, Mertins et al., $2016[78,79]$ \\
\hline & S78 & phos & human, mouse, rat & $\mathrm{x} /-$ & Dephoure et al., 2008, Zanivan et al., 2008, Tweedie-Cullen et al., 2009 [80-82] \\
\hline & S80 & phos & human, mouse, rat & $\mathrm{x} / \mathrm{x}$ & Zhou et al., 2006, Tao et al., 2009, Bracaglia et al., $2009[68,83,84]$ \\
\hline & K82 & ubi & human & $\mathrm{x} /-$ & Gonzales et al., 2012 [19] \\
\hline & S86 & phos & mouse, human & $\mathrm{x} / \mathrm{x}$ & Ebert et al., 2013, Mertins et al., $2014[85,86]$ \\
\hline \multirow{9}{*}{ MBD } & R115 & met & human & $\mathrm{x} /-$ & Geoghegan et al., 2015 [87] \\
\hline & S116 & phos & human & $\mathrm{x} /-$ & Dephoure et al., 2008, Kettenbach et al., 2011, Sharma et al., $2014[77,80,88]$ \\
\hline & K119 & ubi, dimet & human & $\mathrm{x} /-$ & Gonzales et al., 2012, Jung et al., $2008[19,89]$ \\
\hline & Y120 & phos & human, mouse & $x / x$ & Dephoure et al., 2008, Bergo et al., 2015, D’Annessa et al., 2018 [80,90,91] \\
\hline & K135 & ubi & human & $\mathrm{x} /-$ & Gonzales et al., 2012 [19] \\
\hline & T148 & phos & mouse & $\mathrm{x} /-$ & Tao et al., 2009 [84] \\
\hline & S149 & phos & mouse, human & $\mathrm{x} /-$ & Tao et al., 2009, Olsen et al., 2010, Kettenbach et al., $2011[84,88,93]$ \\
\hline & $\mathrm{T} 160$ & phos & mouse & $\mathrm{x} /-$ & Tweedie-Cullen et al., 2009 [82] \\
\hline & R162 & met & mouse, human & $\mathrm{x} /-$ & Guo et al., 2014, Larsen et al., $2016[94,95]$ \\
\hline
\end{tabular}


Table 2. Cont.

\begin{tabular}{|c|c|c|c|c|c|}
\hline & Residue* $^{*}$ & Modification & Species & MS/Other Methods & References** \\
\hline \multirow{19}{*}{ ID } & $163-206$ & PAR & human, mouse, rat & $x / x$ & Jungmichel et al., 2013, Becker et al., $2016[70,96]$ \\
\hline & S164 & phos & mouse & $x / x$ & Tao et al., 2009, Tweedie-Cullen et al., 2009, Stefanelli et al., 2016 [82,84,97] \\
\hline & S166 & phos & mouse, human & $\mathrm{x} /-$ & Huttlin et al., 2010, Yi et al., 2014, Mertins et al., $2014[78,86,98]$ \\
\hline & S178 & phos & human & $\mathrm{x} /-$ & Shiromizu et al., 2013 [75] \\
\hline & $\mathrm{T} 184$ & phos & human, mouse & $\mathrm{x} /-$ & Mertins et al., 2014 [86] \\
\hline & T203 & phos & human & $\mathrm{x} /-$ & Carrier et al., 2016 [99] \\
\hline & S204 & phos & human & $\mathrm{x} /-$ & Carrier et al., 2016 [99] \\
\hline & K210 & dimet & human & $\mathrm{x} /-$ & Jung et al., 2008 [89] \\
\hline & S216 & phos & human (mouse, rat) & $x / x$ & Olsen et al., 2010, Kettenbach et al., 2011, Lombardi et al., $2017[69,88,93]$ \\
\hline & K219 & acet & rat & $\mathrm{x} /-$ & Lundby et al., 2012 [100] \\
\hline & K223 & ubi & human & $\mathrm{x} /-$ & Akimov et al., 2018 [101] \\
\hline & K223 & SUMO & mouse & $-/ x$ & Cheng et al., 2014 [102] \\
\hline & $\mathrm{T} 228^{* * *}$ & phos & human & $\mathrm{x} /-$ & Mertins et al., 2014 [86] \\
\hline & S229 & phos & human, rat (mouse) & $x / x$ & Zhou et al., 2006, Chen et al., 2009, Gonzales et al., 2012 [19,83,103] \\
\hline & K233 & ubi & human & $\mathrm{x} /-$ & Gonzales et al., 2012 [19] \\
\hline & $244-275$ & PAR & human, mouse, rat & $x / x$ & Jungmichel et al., 2013, Becker et al., $2016[70,96]$ \\
\hline & K249 & ubi & human & $\mathrm{x} /-$ & Gonzales et al., 2012 [19] \\
\hline & K256 & ubi & human & $\mathrm{x} /-$ & Gonzales et al., 2012 [19] \\
\hline & K267 & met & human & $\mathrm{x} /-$ & Wu et al., 2015 [104] \\
\hline \multirow{7}{*}{ NID } & K271 & ubi & human & $\mathrm{x} /-$ & Gonzales et al., 2012 [19] \\
\hline & S274 & phos & mouse (human) & $x / x$ & Tweedie-Cullen et al., 2009, Humphrey et al., 2013, Ebert et al., $2013[74,82,85]$ \\
\hline & S292 & phos & mouse, rat & $x / x$ & Humphrey et al., 2013, Liu et al., 2015 [74,105] \\
\hline & S295 & phos & mouse & $x /-$ & Humphrey et al., 2013 [74] \\
\hline & K305 & ubi & human & $\mathrm{x} /-$ & Gonzales et al., 2012 [19] \\
\hline & K307 & ubi, acet & human & $\mathrm{x} /-$ & Gonzales et al., 2012 [19] \\
\hline & T308 & phos & mouse & $-/ x$ & Ebert et al., 2013 [85] \\
\hline
\end{tabular}


Table 2. Cont

\begin{tabular}{|c|c|c|c|c|c|}
\hline & Residue* $^{*}$ & Modification & Species & MS/Other Methods & References** \\
\hline \multirow{18}{*}{ CTD } & T311 & phos & mouse, human & $\mathrm{x} /-$ & Huttlin et al., 2010, Mertins et al., 2014, Parker et al., $2015[78,86,106]$ \\
\hline & S313 & phos & human, mouse & $\mathrm{x} /-$ & Bian et al., 2014, Sharma et al., 2014, Parker et al., $2015[76,77,106]$ \\
\hline & K321 & acet, ubi & human, mouse & $\mathrm{x} /-$ & Gonzales et al., 2012, Beli et al., 2012, Weinert et al., $2013[19,107,108]$ \\
\hline & T327 & phos & human & $\mathrm{x} /-$ & Shiromizu et al., 2013 [75] \\
\hline & S341 & phos & mouse & $\mathrm{x} /-$ & Humphrey et al., 2013 [74] \\
\hline & K347 & met & human & $x / x$ & Dhayalan et al., 2011, Wu et al., $2015[109,110]$ \\
\hline & S357 & phos & human & $\mathrm{x} /-$ & Yang et al., 2006 [111] \\
\hline & S359 & phos & human & $\mathrm{x} /-$ & Yang et al., 2006, Bian et al., 2014 [76,111] \\
\hline & S360 & phos & human, mouse & $\mathrm{x} /-$ & Yang et al., 2006, Grimsrud et al., 2012, Humphrey et al., $2013[74,111,112]$ \\
\hline & S393 & phos & human & $\mathrm{x} /-$ & Bian et al., 2014 [76] \\
\hline & S399 & phos & mouse, rat, human & $\mathrm{x} /-$ & Tao et al., 2009, Gonzales et al., $2012[19,84]$ \\
\hline & S421 & phos & $\begin{array}{c}\text { mouse, rat } \\
\text { (human) }\end{array}$ & $x / x$ & Zhou et al., 2006, Tao et al., 2009, Deng et al., $2010[83,84,113]$ \\
\hline & $\mathrm{T} 434$ & $\mathrm{gl}$ & rat, mouse & $\mathrm{x} /-$ & Wang et al., 2010, Alfaro et al., 2012, Trinidad et al., 2012 [115-117] \\
\hline & T441 & $\mathrm{gl}$ & mouse & $\mathrm{x} /-$ & Alfaro et al., 2012 [116] \\
\hline & $\mathrm{T} 443 / \mathrm{T} 444^{* * *}$ & $\mathrm{gl}$ & rat & $\mathrm{x} /-$ & Wang et al., 2010 [115] \\
\hline & K447 & acet & human & $\mathrm{x} /-$ & Choudhary et al., 2009, Beli et al., 2012, Wu et al., $2015[104,107,118]$ \\
\hline & T477 & phos & human & $\mathrm{x} /-$ & Sharma et al., 2014 [77] \\
\hline & S484 & phos & human, mouse & $\mathrm{x} /-$ & Kettenbach et al., 2011, Schweppe et al., 2013, Mertins et al., $2014[86,88,119]$ \\
\hline
\end{tabular}

Modifications identified by mass spectrometry (MS) might have unclear localization. $x$ means the method as listed above was used, - means it was not used. * modification numbering according to mouse MeCP2 isoform starting in exon 2 (mouse: 484 aa, human: 486 aa, rat: 492 aa) ${ }^{* *}$ references only exemplary (for more information see PhosphositePlus.org) ${ }^{* * *}$ residue numbering according to species mentioned as it differs from mouse. 
Most of the modifications were identified in large scale studies and not further validated by any other assay. Furthermore, in most cases no additional information is available regarding their influence on MeCP2 function (e.g., [74-77,87,88,92]). Many of these PTMs were mapped using a single cell line (e.g., $[74,77,88])$, and their existence in vivo has not been demonstrated. For these reasons, we will focus here on the more detailed studies providing validation and functional relevance of MeCP2 PTMs, in particular, within the context of chromatin.

The first phosphorylation (phos) site identified on MeCP2 was mapped to the CTD on serine 421. S421phos was found as an upshifted band on Western blot analysis upon membrane depolarization [83, $120,121]$ and occurring exclusively in brain, although MeCP2 was detected in many other tissues [122]. S421A/S424A double mutant mice showed better performance in hippocampal memory tests, enhanced longterm potentiation [114] and increased locomotor activity [84]. Analysis of Mecp2 S421A mice revealed an increased dendritic complexity, and defects in the response to novel experiences [123]. As global S421phos was observed upon membrane depolarization, this modification might not regulate expression of specific genes, but rather be involved in modulating global response to membrane depolarization [123].

Together with S421phos, S80phos within the NTD is one of the most studied MeCP2 phosphorylation sites with functional characterization. In contrast to $\$ 421$ phosphorylation, serine 80 was reported to be dephosphorylated upon membrane depolarization and S80A mutant mice show decreased locomotor activity [84]. The modification is highly enriched in the brain and ubiquitously distributed similar to total MeCP2 [84]. S80A mutation decreased MeCP2 chromatin binding affinity, although the MeCP2 S80A protein levels and subcellular distribution did not differ relative to the wildtype MeCP2. Thus, it was suggested that the phosphorylation possibly fine-tunes chromatin association [84]. The homeodomain-interacting protein kinases 1 (HIPK1) and 2 (HIPK2) were proposed to be responsible for MeCP2 phosphorylation at serine 80 [68,69].

Another MeCP2 phosphorylation site influencing chromatin binding affinity was identified on tyrosine 120 within the MBD domain of MeCP2. This tyrosine residue is substituted in a RTT patient by aspartic acid [124], which could mimic the phosphorylated state. MeCP2 Y120D mutation was found to cause a decrease in binding affinity of MeCP2 to heterochromatin [28]. This could be explained at the structural level by computational modeling indicating that MeCP2 Y120D drastically reduces $\mathrm{MeCP} 2$ affinity for DNA as compared to wildtype MeCP2 [91].

A conserved serine (S164) located at the beginning of ID just after the MBD, was shown to be abundantly phosphorylated in the brain in a developmentally regulated manner [97]. While the phospho-mimicking version S164D showed minor binding to chromatin in live-cell kinetic studies, the phospho-defective mutation S164A had the opposite effect [97]. These results could be explained by in silico modeling of the 3D structure of this phosphorylation site, revealing the addition of negative charge to the protein surface as a consequence of S164 phosphorylation, hence, decreasing DNA binding. Immunofluorescence analysis of wildtype neurons versus MeCP2 S164 mutants revealed that temporal regulation of S164 phosphorylation is required for proper nuclear size and neuronal dendritic branching [97].

In addition to phosphorylation, poly(ADP-ribosyl)ation (PAR) of MeCP2 at the ID and TRD domains was reported to occur in vivo in the mouse brain and to influence heterochromatin structure. The addition of this anionic modification within the two highly cationic MeCP2 protein domains responsible to bind DNA was proposed to lead to a general decrease in DNA binding affinity [70]. Concomitantly, poly(ADP-ribosyl)ation of MeCP2 was shown to reduce binding and clustering of pericentric heterochromatin in cell-based assays, suggesting a role of this PTM in MeCP2 chromatin architecture regulation [70].

Altogether, MeCP2 modifications have been shown to regulate its ability to bind and organize DNA/chromatin, as they change the molecular properties of the respective amino acids, which can be critical depending on the position of the residue within the MeCP2 domains. Yet, as mentioned above, most of the modifications identified in $\mathrm{MeCP} 2$ have not been functionally characterized and their role 
in RTT is unclear. The next section will address the consequences of MeCP2 mutations occurring in the context of RTT.

\subsection{MeCP2 RTT Mutations}

MeCP2 was shown to be associated with the neurological disorder Rett syndrome (RTT), as mutations in this gene were found in about $80 \%$ of RTT patients [5]. RTT affects mostly young girls and is characterized by normal development until 7-18 months of age, followed by a developmental stagnation and decline of higher brain functions [125]. Mutations causing RTT and related neurological disorders have been identified along the entire MeCP2 locus, but effects vary depending on the mutation type and location. Missense and nonsense mutations are the most commonly found and relatively well studied. A collection of all RTT related mutations can be found in the online RettBASE: RettSyndrome.org (http://mecp2.chw.edu.au/cgi-bin/mecp2/search/printGraph.cgi). Figure 2 graphically summarizes the high frequency mutations causing RTT (Figure 2) and Table 3 describes their phenotypes.

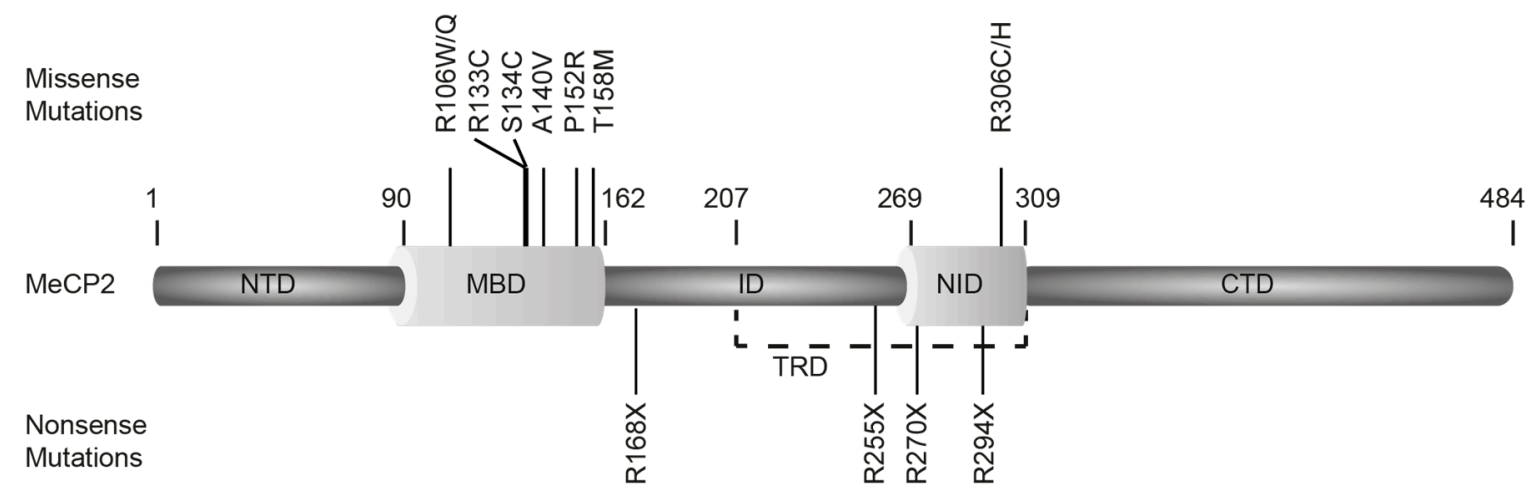

Figure 2. Diagram showing the high frequency mutation spectrum in Rett syndrome patients. A compendium of RTT mutations can be found in the online RettBASE. Missense mutations are shown above and nonsense mutations below the scheme showing the structure of MeCP2 (MeCP2 domains as in Figure 1). X means point mutation to stop codon, thus generating a truncated protein. Amino acids and substitutions are given according to the single-letter nomenclature. Mutation numbering according to human MeCP2 isoform starting in exon 2.

In the following, we will concentrate on RTT mutations impacting MeCP2 DNA binding and chromatin organization function.

$\mathrm{MeCP} 2 \mathrm{RTT}$ related missense mutations are largely found in the MBD, and a large proportion of these mutations reduce the $5 \mathrm{mC}$ binding affinity and, consequently, lead to impaired heterochromatin organization and function in cells [28].

$\mathrm{MeCP} 2 \mathrm{R} 133$ and $\mathrm{R} 111$ residues located within the MDB directly contact $5 \mathrm{mC}$, and mutations at either site decrease MeCP2 localization at heterochromatin in vivo albeit to different extent. MeCP2 R111G is a rare RTT mutation found only in one patient, which abolishes MeCP2 localization to heterochromatin [28]. MeCP2 R133 mutation influences the pericentric heterochromatin localization depending on the amino acid substitution. MeCP2 R133C and R133L decrease the enrichment at heterochromatin, whereas R133H promotes it [28,29]. Furthermore, artificially targeting MeCP2 R111G and R133L mutants to pericentric heterochromatin rescued their ability to cluster heterochromatin [29]. 
Table 3. Summary of high frequency RTT-related MeCP2 point mutations and phenotypes.

\begin{tabular}{|c|c|c|c|c|}
\hline & Mutation & Frequency & Effect on: Mice, Cell, Protein & References \\
\hline \multirow{7}{*}{ MBD } & R106W & 132 & Protein: Abolished methyl-DNA binding ability. & Ballestar et al., 2000 [126] \\
\hline & R106Q & 21 & Protein: Reduced methyl-DNA binding ability. & Yang et al., 2016 [127] \\
\hline & $\mathrm{R} 133 \mathrm{C}$ & 217 & $\begin{array}{l}\text { Mice: Decreased life span of } 42 \text { weeks and body weight. } \\
\text { Protein: Reduced chromatin binding ability. }\end{array}$ & Brown et al., 2015 [128] \\
\hline & $\mathrm{S} 134 \mathrm{C}$ & 21 & Protein: Decreased stability and folding, reduced methyl-DNA binding. & Yang et al., 2016 [127] \\
\hline & A140V & 28 & $\begin{array}{l}\text { Mice: Late onset cognitive regression, pyramidal symptoms, parkinsonism, and bipolar } \\
\text { symptoms. } \\
\text { Increased cell packing density, abnormal dendritic branching of neurons. } \\
\text { Life span: }>14 \text { months. } \\
\text { Cell: Smaller neuron size. } \\
\text { Down-regulation of the mTOR signaling pathway. } \\
\text { Protein: Increased folding stability. }\end{array}$ & $\begin{array}{l}\text { Venkateswaran et al., } 2014 \\
\text { Jentarra et al., } 2010 \\
\text { Ma et al., } 2014 \\
\text { Sampathkumar et al., 2016 } \\
\text { Yang et al., } 2016 \text { [127,129-132] }\end{array}$ \\
\hline & P152R & 71 & Protein: Decreased stability and folding, reduced methyl-DNA binding. & Yang et al., 2016 [127] \\
\hline & $\mathrm{T} 158 \mathrm{M}$ & 419 & $\begin{array}{l}\text { Mice: Decreased life span of } 13 \text { weeks and body weight. } \\
\text { Disturbed nucleolin subcellular localization. } \\
\text { Cell: Reduced neurite outgrowth, reduced dendritic complexity, and impaired } \\
\text { mitochondrial health in forebrain neurons, reduced CREB and phosphorylated CREB levels. } \\
\text { Protein: Decreased protein stability and methyl-DNA binding ability. }\end{array}$ & $\begin{array}{l}\text { Lundvall et al., } 2006 \\
\text { Olson et al., } 2018 \\
\text { Bu et al., } 2017 \\
\text { Chapleau et al., } 2009 \\
\text { Brown et al., } 2015 \text { [128,133-136] }\end{array}$ \\
\hline \multirow[t]{2}{*}{ ID } & R168X & 364 & $\begin{array}{l}\text { Mice: Breathing dysfunction, hind limb clasping and atrophy, hypoactivity. } \\
\text { Decreased life span of } \sim 12 \text { weeks. } \\
\text { Male mice: Impaired motor and cognitive function and reduced anxiety, abnormal hypoxic } \\
\text { and hypercapnic responses, apnea incidence, irregular breath cycle and decreased breathing } \\
\text { rate, enriched outside chromocenters. } \\
\text { Protein: Decreased chromatin compaction ability, decreased methyl-DNA binding. }\end{array}$ & $\begin{array}{l}\text { Lawson-Yuen et al., } 2007 \\
\text { Schaevitz et al., } 2013 \\
\text { Bissonnette et al., } 2014 \\
\text { Georgel et al., } 2003 \\
\text { Yusufzai et al., } 2000 \text { [137-141] }\end{array}$ \\
\hline & $\mathrm{R} 255 \mathrm{X}$ & 313 & $\begin{array}{c}\text { Mice: Decreased brain weight, increased breathing, incidence of arrhythmia, anxiety, motor } \\
\text { and learning impairments. } \\
\text { Cell: mTORC1 pathway abnormalities, decreased nucleolin level, increased } \\
\text { phosphorylation of mTORC2 (S2481) and mTORC1 (S2448). } \\
\text { Protein: Decreased methyl-DNA binding. }\end{array}$ & $\begin{array}{c}\text { Pitcher et al., } 2015 \\
\text { Olson et al., } 2018 \\
\text { Yusufzai et al., } 2000 \\
{[134,141,142]}\end{array}$ \\
\hline
\end{tabular}


Table 3. Cont

\begin{tabular}{|c|c|c|c|c|}
\hline & Mutation & Frequency & Effect on: Mice, Cell, Protein & References \\
\hline \multirow[t]{3}{*}{ NID } & $\mathrm{R} 270 \mathrm{X}$ & 274 & $\begin{array}{l}\text { Male: Severe neonatal encephalopathy and death before } 4 \text { years of age. } \\
\text { Mice: Median life span of } 85 \text { days, increased body weight, decreased brain weight. } \\
\text { Cell: Less athalassemia/mental retardation syndrome X linked (ATRX) foci. } \\
\text { Protein: Decreased methyl-DNA binding, failed to form a higher order structure with } \\
\text { nucleic acids and reduced activity to oligomerize nucleic acids. }\end{array}$ & $\begin{array}{l}\text { Villard et al., } 2007 \\
\text { Baker et al., } 2013 \\
\text { Yusufzai et al., } 2000 \\
{[141,143,144]}\end{array}$ \\
\hline & $\mathrm{R} 294 \mathrm{X}$ & 237 & $\begin{array}{l}\text { Cell: Induce caspase mediated apoptosis, rescued by FoxG1. } \\
\text { Protein: Decreased methyl-DNA binding; decreased stability. }\end{array}$ & $\begin{array}{l}\text { Lundvall et al., } 2006 \\
\text { Yusufzai et al., } 2000[133,141]\end{array}$ \\
\hline & R306C & 245 & $\begin{array}{l}\text { Mice: Hind limb clasping, impaired mobility and motor coordination, reduced brain weight } \\
\text { and size. } \\
\text { Cell: Loss of interaction with NCoR/SMRT. } \\
\text { Protein: Loss of T308 phosphorylation. }\end{array}$ & Lyst et al., 2013 [20] \\
\hline
\end{tabular}

$\mathrm{X}$ means point mutation generating a truncated protein. Mutation numbering according to human MeCP2 isoform starting in exon 2. 
T158 is the most frequently found MeCP2 MBD mutation site in RTT patients and two substitutions have been reported, T158M (frequency 419) and T158A (frequency 2). Neurons expressing MeCP2 T158M showed reduced neurite outgrowth and dendritic complexity by down regulating the expression and phosphorylation of transcriptional activator CREB1 [135,136]. Both MeCP2 T158M and T158A proteins show decreased stability, methyl-DNA binding ability and heterochromatin clustering function $[28,128,139,145]$.

TRD is a second mutational hotspot domain in MeCP2. Considering its function in direct interaction with multiple transcriptional repressor complexes (see Figure 1 and Table 1), mutations within this region are considered to influence the recently proposed MeCP2 'bridge' function between repressors and chromatin $[20,146]$.

$\mathrm{R} 306 \mathrm{C}$ is the most frequent missense mutation found within the MeCP2 TRD. Mutant mice expressing MeCP2 R306C showed typical RTT phenotype: hind limb clasping, impaired mobility and motor coordination, reduced brain weight and size [147]. This mutation did not influence the MeCP2 methyl-DNA binding ability in vitro [128], but showed decreased MeCP2 DNA occupancy in vivo [147], and lack of interaction with NCoR/SMRT [85]. R306C also abolished (neuronal activity-dependent) phosphorylation at the nearby T308 residue. The effect of losing T308 phosphorylation was tested by creating a MeCP2 T308A knock-in mouse model and the analysis of these mutant mice indicated that it contributes to some of the neurological deficits in RTT [85]. Yet, it is still unclear whether the mutation of residue $\mathrm{R} 306$ has an influence on chromatin structure.

In addition to missense mutations, several nonsense RTT mutations have been described within the ID or the TRD. In general, these truncations showed decreased protein stability in vivo and DNA binding affinity in vitro [141].

MeCP2 R168X generates a truncated protein with a deletion of the complete TRD and C-terminal region. Male and female mice with R168X expression showed typical RTT phenotype, but little is known about the underlying mechanism. Although the entire MBD is retained, MeCP2 R168X has impaired ability to form higher order structures as tested by in vitro nucleosomal array (NA) assays [140].

The functional importance of the MeCP2 AT-hooks is highlighted by a comparative study in mice expressing either MeCP2 R270X or MeCP2 G273X (a truncation found in only one male RTT patient), which yielded a different developmental rate and phenotypic progression [148]. MeCP2 R270X mutant mice survived less time than MeCP2 G273X (85 days and 201 days, respectively) due to a disrupted AT-hook 2 (aa 264-273) in the MeCP2 R270 truncation. AT-hook 2 disruption decreased the ability of MeCP2 to promote oligomerization of NA in vitro and mislocalization of chromatin-remodeling protein ATRX in vivo [144].

In summary, the severe phenotypes of RTT patient mutations described above emphasize how essential protein stability, DNA/methyl cytosine binding, interactions with other proteins and ultimately chromatin organization are for proper MeCP2 function in vivo.

\section{3. $\mathrm{MeCP} 2$ in Higher Order Chromatin Compartmentalization}

$\mathrm{MeCP} 2$ is a multifunctional epigenetic reader regulated at multiple levels including, as reviewed above, specific isoforms, interacting factors, post-translational modifications and their interplay within the chromatin context. Yet, it is not well understood how MeCP2 orchestrates genome architecture. In this section, we will summarize findings related to the role of MeCP2 on higher order chromatin organization and propose a unifying model.

\subsection{MeCP2 and Chromatin Looping}

MeCP2 was described to compact nucleosomal arrays (NAs) [140] and to form loops involving undersaturated (DNA partially occupied by nucleosomes) nucleosomal arrays in vitro [24]. While wildtype MeCP2 was shown to form nucleosome-MeCP2-nucleosome 'sandwich' structures bringing two nucleosomes closely together, the RTT truncation mutant R294X was shown to form DNA-MeCP2-DNA 'stem' motifs, bringing nucleosome entry and exit site in close proximity [24]. 
Interestingly, the RTT mutation R106W, which does not bind to methylated DNA (see Table 3), did not induce any chromatin conformations. Thus, MeCP2 loop formation was proposed to proceed in a two step process involving methylation-dependent DNA binding followed by methylation-independent interactions between MeCP2 CTD and nucleosomes [24]. Of note, MeCP2 was also shown to bind to four-way junction DNA, which has a similar conformation as the 'stem' motif [24,149]. Importantly, MeCP2 was proposed to be involved in the formation of a silent chromatin loop at the imprinted Dlx5-Dlx6 locus, and this loop is lost in RTT [150].

Current models though propose that the chromatin loops are promoted by 'loop extrusion', where cohesin extrudes chromatin until it encounters boundaries created by CTCF (CCCTC-binding factor) binding [151,152], albeit the underlying mechanism is unclear. MeCP2 has been reported to interact with ATRX and cohesin subunits SMC1 (structural maintenance of chromosomes protein 1) and SMC3 using coimmunoprecipitation experiments in mouse forebrain [64]. ATRX was proposed to create an extended DNA linker region for CTCF binding [153], and CTCF was reported to promote loop formation together with the cohesin complex [154,155]. Of note, the interaction of MeCP2 with cohesin subunit SMC3 was found to be induced by S229 phosphorylation and inhibited by the S80 phosphorylation of MeCP2 [19], indicating a role of MeCP2 and its modifications on chromatin looping.

Contrary to MeCP2, it was frequently described that CTCF shows a decreased binding affinity to methylated DNA [156,157]. Wang et al. found based on DNA methylome data from 13 cell types that immortalized cells displaying DNA hypermethylation had elevated CTCF level [158]. This might constitute a compensatory mechanism for lower CTCF binding due to hypermethylation [158] and may rescue CTCF mediated insulation of known tumor suppressor genes against methylation dependent silencing $[159,160]$. Furthermore, the $5 \mathrm{mC}$ oxidation product $5 \mathrm{caC}$ was found to enhance CTCF association to DNA and facilitate binding to low affinity CTCF binding motifs [161,162]. As 5mC oxidation to $5 \mathrm{hmC}$ followed by further oxidation to $5 \mathrm{fC}$ and $5 \mathrm{caC}$ was proposed to enable cytosine demethylation ([163], see above), CTCF association to 5caC hints to a CTCF-based mechanism reinforcing its own binding [162]. As MeCP2 has been shown to protect $5 \mathrm{mC}$ from TET mediated oxidation [44], MeCP2 might, thus, influence CTCF binding and DNA loop formation.

As a conclusion, the potential structural and functional interactions between MeCP2 and CTCF are still poorly understood and need to be clarified in further studies, especially considering the importance of both proteins in regulation of chromatin structure and gene expression. Mechanistically, loop formation has been proposed to give rise to TADs, whose boundaries are at least in part defined by CTCF and cohesin [164]. Although there is no evidence directly showing any effects of MeCP2 on TADs, it is still noteworthy to explore if and how MeCP2 organizes TADs, considering the role of $\mathrm{MeCP} 2$ on chromatin looping and counteracting CTCF binding.

\subsection{MeCP2 and Heterochromatin Compartmentalization}

Quantification of MeCP2 in neurons showed it to be nearly as abundant as histone octamers [31]. In MeCP2 deficient neurons, the level of histone $\mathrm{H} 1$ doubled [31], whereas in wild type neurons, the $\mathrm{H} 1$ level was half of the amount of $\mathrm{H} 1$ in other cells [165], indicating that MeCP2 acts as a histone H1-like chromatin linker. Accordingly, MeCP2 was shown: to accelerate $\mathrm{H} 1$ exchange in vivo, hence decreasing dwell time of histone H1 in chromatin [166]; to have a similar mobility to H1 in vivo; and to share with $\mathrm{H} 1$ an overlapping binding site on nucleosomes in vitro [31,166-168]. In fact, by in vitro fluorescence anisotropy assays, it was observed that MeCP2 could replace histone H1 from chromatin [166,169] and globally alter the chromatin state. MeCP2 deficiency was also reported to affect global chromatin composition and state by increasing $\mathrm{H} 3$ acetylation [31]. Hence, MeCP2 was proposed to dampen transcriptional noise from repetitive DNA elements including satellite DNA in a DNA methylation-dependent manner [31]. MeCP2 was also shown to increase H3K9me2 at the promoter of the SIRT1 gene [170] and MeCP2 inhibition was shown to decrease H3K27me3 levels on silenced gene promoters [171], indicating a role of $\mathrm{MeCP} 2$ in facultative heterochromatin regulation. 
On the other hand, $\mathrm{MeCP} 2$ was also reported to activate gene expression by binding the transcription activator CREB1 in euchromatin as mentioned above [17].

Based on the cytological analysis of DNA condensation level, eukaryotic chromatin can be broadly divided into the actively transcribed, open euchromatin and the densely packed, repressed heterochromatin. Heterochromatin is rich in methylated cytosines, which can be specifically recognized by multiple epigenetic readers including MeCP2.

In vivo MeCP2 was shown to be enriched at pericentric heterochromatin [4]. Pericentric heterochromatin is localized in proximity to the centromere and enriched in AT-rich major satellite DNA repeats occupying about $10 \%$ of the mouse genome [172]. In the interphase nucleus, different pericentric heterochromatin regions were shown to fuse and form locally extremely condensed regions called chromocenters [173], a distinct, supra-chromosomal, membraneless heterochromatin domain also enriched in HP1 and H3K9me3. As MeCP2 was shown to interact with HP1 and to colocalize with HP1 in heterochromatin [51] (Table 1), this enables a cross talk between histone methylation and DNA methylation pathways strengthening heterochromatin formation. The influence of $\mathrm{MeCP} 2$ in chromocenter organization was demonstrated by Brero et al. [174], showing that, during myogenic differentiation, the number of chromocenters decreased, i.e., heterochromatin clustered into larger compartments, concomitantly with increased $\mathrm{MeCP} 2$ level and genome methylation. Of note, ectopic MeCP2-YFP could promote pericentric heterochromatin clustering even in the absence of cellular differentiation.

Expanding from this initial study, the role of MeCP2 during neuronal differentiation was analyzed comparing wild type and $\mathrm{MeCP} 2$ deficient mouse embryonic stem cells [175]. An increased MeCP2 level and enrichment at chromocenters was measured during neuronal differentiation, together with significant chromocenter clustering. Accordingly, the chromocenter clustering function was impaired in the MeCP2 deficient mouse embryonic stem cells. Furthermore, ectopic expression of MeCP2 with RTT mutations showed impaired heterochromatin accumulation and decreased chromatin clustering function [28], suggesting a role of heterochromatin organization in RTT.

At the molecular level, using in vitro nucleosomal arrays, Georgel et al. in 2003 observed by electron microscopy that NAs formed both extensively condensed ellipsoidal particles and oligomeric suprastructures upon addition of MeCP2. This was independent of DNA methylation and relying upon regions downstream of $\mathrm{MBD}$, as $\mathrm{R} 168 \mathrm{X}$ truncation mutant failed to assemble oligomeric suprastructures $[140,176]$. This was further confirmed by the observation that the ID, TRD and CTD alpha could bind and compact NAs and that R270X and R273X, truncated within the TRD and missing the whole CTD, could not compact and oligomerize NAs [23,144]. These facts could in part explain how nonsense mutations of MeCP2 lead to severe symptoms of RTT.

It is still far from clear how MeCP2 organizes heterochromatin structure, but emerging evidence suggests a role of phase separation in heterochromatin condensation.

\subsection{Phase Separation and Heterochromatin Condensation}

Compartmentalization of heterochromatin within the cell nucleus is evolutionarily conserved. Recent evidence indicates that in eukaryotic cells, non-membrane bound compartments are present in both the cytoplasm (e.g., stress granules [177]) and the nucleus (e.g., nucleoli [178]) and chromocenters [174]. Although described decades ago, how such membraneless compartments dynamically form and function has been unclear. In 2009, Brangwynne et al. [179] proposed that germline P granules are liquid droplets with fast exchange dynamics, fusion and fission properties and round appearance formed by liquid-liquid phase separation [180], suggesting a possible mechanism for chromatin organization.

Proteins that could undergo phase separation often contain intrinsically disordered regions (IDRs) or low complexity regions (LCRs) [181]. Chemically, the process is based on weak forces (mostly hydrophobic interactions) and multiple electrostatic interactions including charge-charge, charge $-\pi$, $\pi-\pi$ stacking interactions and hydrogen bonds [182-184]. Recent work implicates liquid-liquid phase separation in the nuclear organization, leading to the formation of various subdomains with distinct properties. 
An earlier in vitro cryo-electron microscopy study of purified simian virus 40 minichromosome showed that the purified viral minichromosome was condensed into $10 \mathrm{~nm}$ globules. In high-salt buffer, these globules showed the ability to fuse, whereas at low salt conditions, they opened into filaments and nucleosome strings [185]. Maeshima et al. observed that NAs self-associate into globular oligomers in a cation-induced manner, which can be modulated by histone H1 and linker DNA [186]. Altogether, these studies suggest a 'liquid drop' model of chromosome organization.

More recently, NAs were shown to undergo histone tail dependent liquid-like phase separation in physiologic salt conditions, a phenomenon promoted by histone H1, controlled by linker DNA length and disrupted by histone acetylation [187]. Furthermore, NAs with acetylated histones could form a new liquid phase with multi-bromodomain proteins, and these droplets had distinct properties compared to droplets formed by unmodified histones.

Two recent studies found that HP1alpha protein could drive chromocenter formation via phase separation $[188,189]$, linking phase separation to chromocenter structure and dynamics via multivalent interactions. Interestingly, MeCP2 was shown to have a highly unstructured nature [33] and to induce the formation of very large heterochromatin clusters when compared with HP1 [174]. Altogether, these studies suggest a framework to understand chromatin compartmentalization based on liquid-liquid phase separation.

\subsection{Model for MeCP2 Function in Chromocenter Clustering}

In summary, as described in the sections above, MeCP2 interacts with DNA, methyl cytosines and nucleosomes via separate domains, and interacts with several chromatin proteins. Furthermore, $\mathrm{MeCP} 2$ can replace linker histone $\mathrm{H} 1$ and has a highly unstructured nature. Firstly, like most proteins that could form liquid phase separation, $\mathrm{MeCP} 2$ intrinsically disordered regions consist of mainly positively charged residues (arginines, histidines and lysines). These residues form electrostatic interactions with the negatively charged amino acids in other proteins and phosphates in DNA or RNA, thus, building multivalent protein-protein/DNA/RNA interactions. Such interactions locally enrich or deplete factors in a dynamic manner, while being sensitive to post-translational modifications (a described above). Secondly, MeCP2 foci exhibit liquid-like properties in vivo. Brero et al. showed that $\mathrm{MeCP} 2$ forms round-shaped foci within the cell nucleus and foci in close proximity tend to fuse over time. Furthermore, during mitosis, these chromatin clusters undergo fission and reform again after cells have divided. MeCP2 was also shown to promote chromocenter clustering in a dose dependent manner [174]. In addition, purified MeCP2 protein alone showed oblate ellipsoid appearance in electron microscopy analysis [24]. Hence, and as depicted graphically in Figure 3, we propose that the multivalent interactions with proteins and DNA/nucleosomes, together with its ability to oligomerize and possibly create by itself phase separated compartments, altogether contribute to the in vivo ability of MeCP2 to dynamically and efficiently cluster and compartmentalize heterochromatin. 


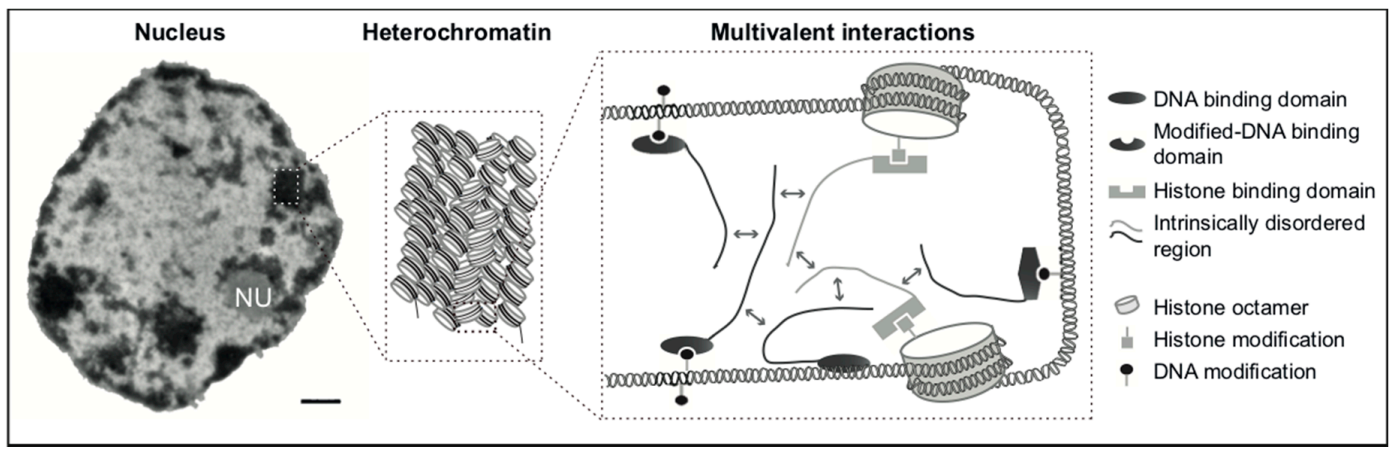

Figure 3. Role of multivalent interactions in heterochromatin formation. Left: transmission electron microscopy image of a mouse liver cell nucleus at interphase with electron dense regions corresponding to heterochromatin and electron light regions corresponding to euchromatin. NU: nucleoli. Scale bar = $0.5 \mu \mathrm{m}$. Middle: graphical representation of heterochromatin. Nucleosomes are tightly packed within heterochromatin and show limited accessibility to multiple factors binding DNA. Right: cartoon showing multivalent interactions that promote heterochromatin formation. Chromatin compaction can be maintained by multivalent interactions involving DNA and multiple proteins. Unmethylated, methylated DNA and posttranslational modifications of histones could recruit multiple protein factors containing intrinsically disordered regions (IDR) (like MeCP2 and HP1). Via these IDR regions multivalent homo and hetero weak interactions take place, promoting the formation of heterochromatin possibly by phase separation.

Author Contributions: Conceptualization, A.S., H.Z., M.C.C.; writing original draft preparation, A.S., H.Z.; writing-review and editing, M.C.C.; funding acquisition, M.C.C. All authors have read and agreed to the published version of the manuscript.

Funding: Our research has been supported by grants of the German Research Foundation (DFG CA 198/10-1 and 16-1 to MCC). H.Z. is funded by a fellowship of the China Scholarship Council.

Acknowledgments: We thank all the past and present members of our laboratory for their many contributions along the years and our collaborators.

Conflicts of Interest: The authors declare no conflict of interest.

$\begin{array}{ll}\text { Abbreviations } \\ 5 \mathrm{caC} & \text { 5-carboxycytosine } \\ 5 \mathrm{fC} & \text { 5-formylcytosine } \\ 5 \mathrm{hmC} & \text { 5-hydroxymethylcytosine } \\ 5 \mathrm{mC} & \text { 5-methylcytosine } \\ \text { acet } & \text { acetylation } \\ \text { ATRX } & \text { a-thalassemia/mental retardation syndrome X linked } \\ \text { C } & \text { cytosine } \\ \text { CREB } & \text { cyclic AMP-responsive element-binding protein } \\ \text { CTCF } & \text { CCCTC-binding factor } \\ \text { CTD } & \text { C-terminal domain } \\ \text { (di)met } & \text { (di)methylation } \\ \text { gl } & \text { N-acetylglucosamine } \\ \text { HDAC } & \text { histone deacetylase } \\ \text { HP1 } & \text { heterochromatin protein 1 } \\ \text { ID } & \text { intervening domain } \\ \text { MBD } & \text { methyl-CpG-binding domain } \\ \text { MeCP2 } & \text { methyl-CpG binding protein 2 } \\ \text { NA } & \text { nucleosomal array }\end{array}$




$\begin{array}{ll}\text { NID } & \text { NCoR/SMRT interaction domain } \\ \text { NTD } & \text { N-terminal domain } \\ \text { PAR } & \text { poly(ADP-ribosyl)ation } \\ \text { phos } & \text { phosphorylation } \\ \text { PTM } & \text { post-translational modification } \\ \text { RTT } & \text { Rett syndrome } \\ \text { TAD } & \text { topologically associated domain } \\ \text { TET } & \text { Ten-eleven translocation } \\ \text { TRD } & \text { transcriptional repression domain } \\ \text { ubi } & \text { ubiquitination } \\ \text { YB-1 } & \text { Y box-binding protein 1 }\end{array}$

\section{References}

1. Szabo, Q.; Bantignies, F.; Cavalli, G. Principles of genome folding into topologically associating domains. Sci. Adv. 2019, 5, eaaw1668. [CrossRef] [PubMed]

2. Klemm, S.L.; Shipony, Z.; Greenleaf, W.J. Chromatin accessibility and the regulatory epigenome. Nat. Rev. Genet. 2019, 20, 207-220. [CrossRef] [PubMed]

3. Rausch, C.; Hastert, F.D.; Cardoso, M.C. DNA Modification Readers and Writers and Their Interplay. J. Mol. Biol. 2019, 432, 1731-1746. [CrossRef] [PubMed]

4. Lewis, J.D.; Meehan, R.R.; Henzel, W.J.; Maurer-Fogy, I.; Jeppesen, P.; Klein, F.; Bird, A. Purification, sequence, and cellular localization of a novel chromosomal protein that binds to methylated DNA. Cell 1992, 69, 905-914. [CrossRef]

5. Amir, R.E.; Van den Veyver, I.B.; Wan, M.; Tran, C.Q.; Francke, U.; Zoghbi, H.Y. Rett syndrome is caused by mutations in X-linked MECP2, encoding methyl-CpG-binding protein 2. Nat. Genet. 1999, 23, 185-188. [CrossRef]

6. Olson, C.O.; Zachariah, R.M.; Ezeonwuka, C.D.; Liyanage, V.R.; Rastegar, M. Brain region-specific expression of MeCP2 isoforms correlates with DNA methylation within Mecp2 regulatory elements. PLoS ONE 2014, 9, e90645. [CrossRef]

7. Li, Y.; Wang, H.; Muffat, J.; Cheng, A.W.; Orlando, D.A.; Lovén, J.; Kwok, S.-m.; Feldman, D.A.; Bateup, H.S.; Gao, Q. Global transcriptional and translational repression in human-embryonic-stem-cell-derived Rett syndrome neurons. Cell Stem Cell 2013, 13, 446-458. [CrossRef]

8. Fichou, Y.; Nectoux, J.; Bahi-Buisson, N.; Rosas-Vargas, H.; Girard, B.; Chelly, J.; Bienvenu, T. The first missense mutation causing Rett syndrome specifically affecting the MeCP2_e1 isoform. Neurogenetics 2009, 10, 127. [CrossRef]

9. Saunders, C.J.; Minassian, B.E.; Chow, E.W.; Zhao, W.; Vincent, J.B. Novel exon 1 mutations in MECP2 implicate isoform MeCP2_e1 in classical Rett syndrome. Am. J. Med. Genet. Part A 2009, 149, 1019-1023. [CrossRef]

10. Sheikh, T.I.; de Paz, A.M.; Akhtar, S.; Ausió, J.; Vincent, J.B. MeCP2_E1 N-terminal modifications affect its degradation rate and are disrupted by the Ala2Val Rett mutation. Hum. Mol. Genet. 2017, 26, 4132-4141. [CrossRef]

11. Nan, X.; Ng, H.H.; Johnson, C.A.; Laherty, C.D.; Turner, B.M.; Eisenman, R.N.; Bird, A. Transcriptional repression by the methyl-CpG-binding protein MeCP2 involves a histone deacetylase complex. Nature 1998, 393, 386-389. [CrossRef] [PubMed]

12. Jones, P.L.; Veenstra, G.J.; Wade, P.A.; Vermaak, D.; Kass, S.U.; Landsberger, N.; Strouboulis, J.; Wolffe, A.P. Methylated DNA and MeCP2 recruit histone deacetylase to repress transcription. Nat. Genet. 1998, 19, 187-191. [CrossRef] [PubMed]

13. Lunyak, V.V.; Burgess, R.; Prefontaine, G.G.; Nelson, C.; Sze, S.H.; Chenoweth, J.; Schwartz, P.; Pevzner, P.A.; Glass, C.; Mandel, G.; et al. Corepressor-dependent silencing of chromosomal regions encoding neuronal genes. Science 2002, 298, 1747-1752. [CrossRef] [PubMed]

14. Kokura, K.; Kaul, S.C.; Wadhwa, R.; Nomura, T.; Khan, M.M.; Shinagawa, T.; Yasukawa, T.; Colmenares, C.; Ishii, S. The Ski protein family is required for MeCP2-mediated transcriptional repression. J. Biol. Chem. 2001, 276, 34115-34121. [CrossRef] [PubMed] 
15. Suzuki, M.; Yamada, T.; Kihara-Negishi, F.; Sakurai, T.; Oikawa, T. Direct association between PU.1 and $\mathrm{MeCP} 2$ that recruits mSin3A-HDAC complex for PU.1-mediated transcriptional repression. Oncogene 2003, 22, 8688-8698. [CrossRef]

16. Forlani, G.; Giarda, E.; Ala, U.; Di Cunto, F.; Salani, M.; Tupler, R.; Kilstrup-Nielsen, C.; Landsberger, N. The MeCP2/YY1 interaction regulates ANT1 expression at 4q35: Novel hints for Rett syndrome pathogenesis. Hum. Mol. Genet. 2010, 19, 3114-3123. [CrossRef]

17. Chahrour, M.; Jung, S.Y.; Shaw, C.; Zhou, X.; Wong, S.T.; Qin, J.; Zoghbi, H.Y. MeCP2, a key contributor to neurological disease, activates and represses transcription. Science 2008, 320, 1224-1229. [CrossRef]

18. Leoh, L.S.; van Heertum, B.; De Rijck, J.; Filippova, M.; Rios-Colon, L.; Basu, A.; Martinez, S.R.; Tungteakkhun, S.S.; Filippov, V.; Christ, F.; et al. The stress oncoprotein LEDGF/p75 interacts with the methyl CpG binding protein MeCP2 and influences its transcriptional activity. Mol. Cancer Res. 2012, 10, 378-391. [CrossRef]

19. Gonzales, M.L.; Adams, S.; Dunaway, K.W.; LaSalle, J.M. Phosphorylation of distinct sites in MeCP2 modifies cofactor associations and the dynamics of transcriptional regulation. Mol. Cell. Biol. 2012, 32, 2894-2903. [CrossRef]

20. Lyst, M.J.; Ekiert, R.; Ebert, D.H.; Merusi, C.; Nowak, J.; Selfridge, J.; Guy, J.; Kastan, N.R.; Robinson, N.D.; de Lima Alves, F. Rett syndrome mutations abolish the interaction of MeCP2 with the NCoR/SMRT co-repressor. Nat. Neurosci. 2013, 16, 898-902. [CrossRef]

21. Nan, X.S.; Meehan, R.R.; Bird, A. Dissection of the Methyl-Cpg Binding Domain from the Chromosomal Protein Mecp2. Nucleic Acids Res. 1993, 21, 4886-4892. [CrossRef]

22. Meehan, R.R.; Lewis, J.D.; Bird, A.P. Characterization of Mecp2, a Vertebrate DNA-Binding Protein with Affinity for Methylated DNA. Nucleic Acids Res. 1992, 20, 5085-5092. [CrossRef] [PubMed]

23. Ghosh, R.P.; Nikitina, T.; Horowitz-Scherer, R.A.; Gierasch, L.M.; Uversky, V.N.; Hite, K.; Hansen, J.C.; Woodcock, C.L. Unique Physical Properties and Interactions of the Domains of Methylated DNA Binding Protein 2. Biochemistry 2010, 49, 4395-4410. [CrossRef] [PubMed]

24. Nikitina, T.; Shi, X.; Ghosh, R.P.; Horowitz-Scherer, R.A.; Hansen, J.C.; Woodcock, C.L. Multiple modes of interaction between the methylated DNA binding protein MeCP2 and chromatin. Mol. Cell. Biol. 2007, 27, 864-877. [CrossRef] [PubMed]

25. Lyst, M.J.; Connelly, J.; Merusi, C.; Bird, A. Sequence-specific DNA binding by AT-hook motifs in Me CP 2. FEBS Lett. 2016, 590, 2927-2933. [CrossRef]

26. Wakefield, R.I.; Smith, B.O.; Nan, X.; Free, A.; Soteriou, A.; Uhrin, D.; Bird, A.P.; Barlow, P.N. The solution structure of the domain from MeCP2 that binds to methylated DNA. J. Mol. Biol. 1999, 291, 1055-1065. [CrossRef]

27. Ho, K.L.; Mcnae, L.W.; Schmiedeberg, L.; Klose, R.J.; Bird, A.P.; Walkinshaw, M.D. MeCP2 binding to DNA depends upon hydration at methyl-CpG. Mol. Cell 2008, 29, 525-531. [CrossRef]

28. Agarwal, N.; Becker, A.; Jost, K.L.; Haase, S.; Thakur, B.K.; Brero, A.; Hardt, T.; Kudo, S.; Leonhardt, H.; Cardoso, M.C. MeCP2 Rett mutations affect large scale chromatin organization. Hum. Mol. Genet. 2011, 20, 4187-4195. [CrossRef]

29. Casas-Delucchi, C.S.; Becker, A.; Bolius, J.J.; Cardoso, M.C. Targeted manipulation of heterochromatin rescues MeCP2 Rett mutants and re-establishes higher order chromatin organization. Nucleic Acids Res. 2012, 40, e176. [CrossRef]

30. Hansen, J.C.; Wexler, B.B.; Rogers, D.J.; Hite, K.C.; Panchenko, T.; Ajith, S.; Black, B.E. DNA Binding Restricts the Intrinsic Conformational Flexibility of Methyl CpG Binding Protein 2 (MeCP2). J. Biol. Chem. 2011, 286, 18938-18948. [CrossRef]

31. Skene, P.J.; Illingworth, R.S.; Webb, S.; Kerr, A.R.; James, K.D.; Turner, D.J.; Andrews, R.; Bird, A.P. Neuronal $\mathrm{MeCP} 2$ is expressed at near histone-octamer levels and globally alters the chromatin state. Mol. Cell 2010, 37, 457-468. [CrossRef] [PubMed]

32. Yasui, D.H.; Peddada, S.; Bieda, M.C.; Vallero, R.O.; Hogart, A.; Nagarajan, R.P.; Thatcher, K.N.; Farnham, P.J.; LaSalle, J.M. Integrated epigenomic analyses of neuronal MeCP2 reveal a role for long-range interaction with active genes. Proc. Natl. Acad. Sci. USA 2007, 104, 19416-19421. [CrossRef] [PubMed]

33. Adams, V.H.; McBryant, S.J.; Wade, P.A.; Woodcock, C.L.; Hansen, J.C. Intrinsic disorder and autonomous domain function in the multifunctional nuclear protein, MeCP2. J. Biol. Chem. 2007, 282, 15057-15064. [CrossRef] [PubMed] 
34. Lagger, S.; Connelly, J.C.; Schweikert, G.; Webb, S.; Selfridge, J.; Ramsahoye, B.H.; Yu, M.; He, C.; Sanguinetti, G.; Sowers, L.C.; et al. MeCP2 recognizes cytosine methylated tri-nucleotide and di-nucleotide sequences to tune transcription in the mammalian brain. PLoS Genet. 2017, 13, e1006793. [CrossRef]

35. Mo, A.; Mukamel, E.A.; Davis, F.P.; Luo, C.; Henry, G.L.; Picard, S.; Urich, M.A.; Nery, J.R.; Sejnowski, T.J.; Lister, R.; et al. Epigenomic Signatures of Neuronal Diversity in the Mammalian Brain. Neuron 2015, 86, 1369-1384. [CrossRef] [PubMed]

36. Renthal, W.; Boxer, L.D.; Hrvatin, S.; Li, E.; Silberfeld, A.; Nagy, M.A.; Griffith, E.C.; Vierbuchen, T.; Greenberg, M.E. Characterization of human mosaic Rett syndrome brain tissue by single-nucleus RNA sequencing. Nat. Neurosci. 2018, 21, 1670-1679. [CrossRef] [PubMed]

37. Mellen, M.; Ayata, P.; Dewell, S.; Kriaucionis, S.; Heintz, N. MeCP2 Binds to 5hmC Enriched within Active Genes and Accessible Chromatin in the Nervous System. Cell 2012, 151, 1417-1430. [CrossRef] [PubMed]

38. Spruijt, C.G.; Gnerlich, F.; Smits, A.H.; Pfaffeneder, T.; Jansen, P.W.T.C.; Bauer, C.; Munzel, M.; Wagner, M.; Muller, M.; Khan, F.; et al. Dynamic Readers for 5-(Hydroxy)Methylcytosine and Its Oxidized Derivatives. Cell 2013, 152, 1146-1159. [CrossRef]

39. Ludwig, A.K.; Zhang, P.; Cardoso, M.C. Modifiers and Readers of DNA Modifications and Their Impact on Genome Structure, Expression, and Stability in Disease. Front. Genet. 2016, 7, 115. [CrossRef]

40. Szulwach, K.E.; Li, X.; Li, Y.; Song, C.X.; Wu, H.; Dai, Q.; Irier, H.; Upadhyay, A.K.; Gearing, M.; Levey, A.I.; et al. 5-hmC-mediated epigenetic dynamics during postnatal neurodevelopment and aging. Nat. Neurosci. 2011, 14, 1607-1616. [CrossRef]

41. Frauer, C.; Hoffmann, T.; Bultmann, S.; Casa, V.; Cardoso, M.C.; Antes, I.; Leonhardt, H. Recognition of 5-hydroxymethylcytosine by the Uhrf1 SRA domain. PLoS ONE 2011, 6, e21306. [CrossRef] [PubMed]

42. Chen, L.; Chen, K.; Lavery, L.A.; Baker, S.A.; Shaw, C.A.; Li, W.; Zoghbi, H.Y. MeCP2 binds to non-CG methylated DNA as neurons mature, influencing transcription and the timing of onset for Rett syndrome. Proc. Natl. Acad. Sci. USA 2015, 112, 5509-5514. [CrossRef] [PubMed]

43. Kinde, B.; Gabel, H.W.; Gilbert, C.S.; Griffith, E.C.; Greenberg, M.E. Reading the unique DNA methylation landscape of the brain: Non-CpG methylation, hydroxymethylation, and MeCP2. Proc. Natl. Acad. Sci. USA 2015, 112, 6800-6806. [CrossRef] [PubMed]

44. Ludwig, A.K.; Zhang, P.; Hastert, F.D.; Meyer, S.; Rausch, C.; Herce, H.D.; Muller, U.; Lehmkuhl, A.; Hellmann, I.; Trummer, C.; et al. Binding of MBD proteins to DNA blocks Tet1 function thereby modulating transcriptional noise. Nucleic Acids Res. 2017, 45, 2438-2457. [CrossRef]

45. Muotri, A.R.; Marchetto, M.C.; Coufal, N.G.; Oefner, R.; Yeo, G.; Nakashima, K.; Gage, F.H. L1 retrotransposition in neurons is modulated by MeCP2. Nature 2010, 468, 443-446. [CrossRef]

46. Yu, F.; Zingler, N.; Schumann, G.; Stratling, W.H. Methyl-CpG-binding protein 2 represses LINE-1 expression and retrotransposition but not Alu transcription. Nucleic Acids Res. 2001, 29, 4493-4501. [CrossRef]

47. Zhang, P.; Ludwig, A.K.; Hastert, F.D.; Rausch, C.; Lehmkuhl, A.; Hellmann, I.; Smets, M.; Leonhardt, H.; Cardoso, M.C. L1 retrotransposition is activated by Ten-eleven-translocation protein 1 and repressed by methyl-CpG binding proteins. Nucleus 2017, 8, 548-562. [CrossRef]

48. Fuks, F.; Hurd, P.J.; Wolf, D.; Nan, X.; Bird, A.P.; Kouzarides, T. The methyl-CpG-binding protein MeCP2 links DNA methylation to histone methylation. J. Biol. Chem. 2003, 278, 4035-4040. [CrossRef]

49. Lachner, M.; O'Carroll, N.; Rea, S.; Mechtler, K.; Jenuwein, T. Methylation of histone H3 lysine 9 creates a binding site for HP1 proteins. Nature 2001, 410, 116-120. [CrossRef]

50. Bannister, A.J.; Zegerman, P.; Partridge, J.F.; Miska, E.A.; Thomas, J.O.; Allshire, R.C.; Kouzarides, T. Selective recognition of methylated lysine 9 on histone H3 by the HP1 chromo domain. Nature 2001, 410, 120-124. [CrossRef]

51. Agarwal, N.; Hardt, T.; Brero, A.; Nowak, D.; Rothbauer, U.; Becker, A.; Leonhardt, H.; Cardoso, M.C. MeCP2 interacts with HP1 and modulates its heterochromatin association during myogenic differentiation. Nucleic Acids Res. 2007, 35, 5402-5408. [CrossRef] [PubMed]

52. Yamamoto, K.; Sonoda, M. Self-interaction of heterochromatin protein 1 is required for direct binding to histone methyltransferase, SUV39H1. Biochem. Biophys. Res. Commun. 2003, 301, 287-292. [CrossRef]

53. Kimura, H.; Shiota, K. Methyl-CpG-binding protein, MeCP2, is a target molecule for maintenance DNA methyltransferase, Dnmt1. J. Biol. Chem. 2003, 278, 4806-4812. [CrossRef] [PubMed]

54. Fuks, F.; Burgers, W.A.; Brehm, A.; Hughes-Davies, L.; Kouzarides, T. DNA methyltransferase Dnmt1 associates with histone deacetylase activity. Nat. Genet. 2000, 24, 88-91. [CrossRef] [PubMed] 
55. Rountree, M.R.; Bachman, K.E.; Baylin, S.B. DNMT1 binds HDAC2 and a new co-repressor, DMAP1, to form a complex at replication foci. Nat. Genet. 2000, 25, 269-277. [CrossRef] [PubMed]

56. Becker, A.; Allmann, L.; Hofstatter, M.; Casa, V.; Weber, P.; Lehmkuhl, A.; Herce, H.D.; Cardoso, M.C. Direct homo- and hetero-interactions of MeCP2 and MBD2. PLoS ONE 2013, 8, e53730. [CrossRef] [PubMed]

57. Nan, X.; Hou, J.; Maclean, A.; Nasir, J.; Lafuente, M.J.; Shu, X.; Kriaucionis, S.; Bird, A. Interaction between chromatin proteins MECP2 and ATRX is disrupted by mutations that cause inherited mental retardation. Proc. Natl. Acad. Sci. USA 2007, 104, 2709-2714. [CrossRef]

58. Bedford, M.T.; Chan, D.C.; Leder, P. FBP WW domains and the Abl SH3 domain bind to a specific class of proline-rich ligands. EMBO J. 1997, 16, 2376-2383. [CrossRef]

59. Buschdorf, J.P.; Stratling, W.H. A WW domain binding region in methyl-CpG-binding protein MeCP2: Impact on Rett syndrome. J. Mol. Med. 2004, 82, 135-143. [CrossRef]

60. Young, J.I.; Hong, E.P.; Castle, J.C.; Crespo-Barreto, J.; Bowman, A.B.; Rose, M.F.; Kang, D.; Richman, R.; Johnson, J.M.; Berget, S.; et al. Regulation of RNA splicing by the methylation-dependent transcriptional repressor methyl-CpG binding protein 2. Proc. Natl. Acad. Sci. USA 2005, 102, 17551-17558. [CrossRef]

61. Ren, J.; Wen, L.; Gao, X.; Jin, C.; Xue, Y.; Yao, X. DOG 1.0: Illustrator of protein domain structures. Cell Res. 2009, 19, 271-273. [CrossRef] [PubMed]

62. Matsumura, S.; Persson, L.M.; Wong, L.; Wilson, A.C. The latency-associated nuclear antigen interacts with MeCP2 and nucleosomes through separate domains. J. Virol. 2010, 84, 2318-2330. [CrossRef] [PubMed]

63. Krithivas, A.; Fujimuro, M.; Weidner, M.; Young, D.B.; Hayward, S.D. Protein interactions targeting the latency-associated nuclear antigen of Kaposi's sarcoma-associated herpesvirus to cell chromosomes. J. Virol. 2002, 76, 11596-11604. [CrossRef] [PubMed]

64. Kernohan, K.D.; Jiang, Y.; Tremblay, D.C.; Bonvissuto, A.C.; Eubanks, J.H.; Mann, M.R.; Berube, N.G. ATRX partners with cohesin and MeCP2 and contributes to developmental silencing of imprinted genes in the brain. Dev. Cell 2010, 18, 191-202. [CrossRef]

65. Harikrishnan, K.N.; Chow, M.Z.; Baker, E.K.; Pal, S.; Bassal, S.; Brasacchio, D.; Wang, L.; Craig, J.M.; Jones, P.L.; Sif, S.; et al. Brahma links the SWI/SNF chromatin-remodeling complex with MeCP2-dependent transcriptional silencing. Nat. Genet. 2005, 37, 254-264. [CrossRef]

66. Long, S.W.; Ooi, J.Y.; Yau, P.M.; Jones, P.L. A brain-derived MeCP2 complex supports a role for MeCP2 in RNA processing. Biosci. Rep. 2011, 31, 333-343. [CrossRef]

67. Jeffery, L.; Nakielny, S. Components of the DNA methylation system of chromatin control are RNA-binding proteins. J. Biol. Chem. 2004, 279, 49479-49487. [CrossRef]

68. Bracaglia, G.; Conca, B.; Bergo, A.; Rusconi, L.; Zhou, Z.; Greenberg, M.E.; Landsberger, N.; Soddu, S.; Kilstrup-Nielsen, C. Methyl-CpG-binding protein 2 is phosphorylated by homeodomain-interacting protein kinase 2 and contributes to apoptosis. EMBO Rep. 2009, 10, 1327-1333. [CrossRef]

69. Lombardi, L.M.; Zaghlula, M.; Sztainberg, Y.; Baker, S.A.; Klisch, T.J.; Tang, A.A.; Huang, E.J.; Zoghbi, H.Y. An RNA interference screen identifies druggable regulators of MeCP2 stability. Sci. Transl. Med. 2017, 9. [CrossRef]

70. Becker, A.; Zhang, P.; Allmann, L.; Meilinger, D.; Bertulat, B.; Eck, D.; Hofstaetter, M.; Bartolomei, G.; Hottiger, M.O.; Schreiber, V. Poly (ADP-ribosyl) ation of methyl CpG binding domain protein 2 regulates chromatin structure. J. Biol. Chem. 2016, 291, 4873-4881. [CrossRef]

71. Mari, F.; Azimonti, S.; Bertani, I.; Bolognese, F.; Colombo, E.; Caselli, R.; Scala, E.; Longo, I.; Grosso, S.; Pescucci, C.; et al. CDKL5 belongs to the same molecular pathway of MeCP2 and it is responsible for the early-onset seizure variant of Rett syndrome. Hum. Mol. Genet. 2005, 14, 1935-1946. [CrossRef] [PubMed]

72. Lin, C.; Franco, B.; Rosner, M.R. CDKL5/Stk9 kinase inactivation is associated with neuronal developmental disorders. Hum. Mol. Genet. 2005, 14, 3775-3786. [CrossRef] [PubMed]

73. Hornbeck, P.V.; Zhang, B.; Murray, B.; Kornhauser, J.M.; Latham, V.; Skrzypek, E. PhosphoSitePlus, 2014: Mutations, PTMs and recalibrations. Nucleic Acids Res. 2015, 43, D512-D520. [CrossRef] [PubMed]

74. Humphrey, S.J.; Yang, G.; Yang, P.; Fazakerley, D.J.; Stockli, J.; Yang, J.Y.; James, D.E. Dynamic adipocyte phosphoproteome reveals that Akt directly regulates mTORC2. Cell Metab. 2013, 17, 1009-1020. [CrossRef] [PubMed] 
75. Shiromizu, T.; Adachi, J.; Watanabe, S.; Murakami, T.; Kuga, T.; Muraoka, S.; Tomonaga, T. Identification of Missing Proteins in the neXtProt Database and Unregistered Phosphopeptides in the PhosphoSitePlus Database as Part of the Chromosome-Centric Human Proteome Project. J. Proteome Res. 2013, 12, 2414-2421. [CrossRef]

76. Bian, Y.; Song, C.; Cheng, K.; Dong, M.; Wang, F.; Huang, J.; Sun, D.; Wang, L.; Ye, M.; Zou, H. An enzyme assisted RP-RPLC approach for in-depth analysis of human liver phosphoproteome. J. Proteom. 2014, 96, $253-262$. [CrossRef]

77. Sharma, K.; D’Souza, R.C.J.; Tyanova, S.; Schaab, C.; Wisniewski, J.R.; Cox, J.; Mann, M. Ultradeep Human Phosphoproteome Reveals a Distinct Regulatory Nature of Tyr and Ser/Thr-Based Signaling. Cell Rep. 2014, 8, 1583-1594. [CrossRef]

78. Huttlin, E.L.; Jedrychowski, M.P.; Elias, J.E.; Goswami, T.; Rad, R.; Beausoleil, S.A.; Villen, J.; Haas, W.; Sowa, M.E.; Gygi, S.P. A tissue-specific atlas of mouse protein phosphorylation and expression. Cell 2010, 143, 1174-1189. [CrossRef]

79. Mertins, P.; Mani, D.R.; Ruggles, K.V.; Gillette, M.A.; Clauser, K.R.; Wang, P.; Wang, X.; Qiao, J.W.; Cao, S.; Petralia, F.; et al. Proteogenomics connects somatic mutations to signalling in breast cancer. Nature 2016, 534, 55-62. [CrossRef]

80. Dephoure, N.; Zhou, C.; Villen, J.; Beausoleil, S.A.; Bakalarski, C.E.; Elledge, S.J.; Gygi, S.P. A quantitative atlas of mitotic phosphorylation. Proc. Natl. Acad. Sci. USA 2008, 105, 10762-10767. [CrossRef]

81. Zanivan, S.; Gnad, F.; Wickstrom, S.A.; Geiger, T.; Macek, B.; Cox, J.; Fassler, R.; Mann, M. Solid tumor proteome and phosphoproteome analysis by high resolution mass spectrometry. J. Proteome Res. 2008, 7, 5314-5326. [CrossRef] [PubMed]

82. Tweedie-Cullen, R.Y.; Reck, J.M.; Mansuy, I.M. Comprehensive mapping of post-translational modifications on synaptic, nuclear, and histone proteins in the adult mouse brain. J. Proteome Res. 2009, 8, 4966-4982. [CrossRef] [PubMed]

83. Zhou, Z.; Hong, E.J.; Cohen, S.; Zhao, W.N.; Ho, H.Y.; Schmidt, L.; Chen, W.G.; Lin, Y.; Savner, E.; Griffith, E.C.; et al. Brain-specific phosphorylation of $\mathrm{MeCP} 2$ regulates activity-dependent Bdnf transcription, dendritic growth, and spine maturation. Neuron 2006, 52, 255-269. [CrossRef] [PubMed]

84. Tao, J.F.; Hu, K.P.; Chang, Q.; Wu, H.; Sherman, N.E.; Martinowich, K.; Klose, R.J.; Schanen, C.; Jaenisch, R.; Wang, W.D.; et al. Phosphorylation of MeCP2 at Serine 80 regulates its chromatin association and neurological function. Proc. Natl. Acad. Sci. USA 2009, 106, 4882-4887. [CrossRef] [PubMed]

85. Ebert, D.H.; Gabel, H.W.; Robinson, N.D.; Kastan, N.R.; Hu, L.S.; Cohen, S.; Navarro, A.J.; Lyst, M.J.; Ekiert, R.; Bird, A.P. Activity-dependent phosphorylation of MeCP2 threonine 308 regulates interaction with NCoR. Nature 2013, 499, 341-345. [CrossRef]

86. Mertins, P.; Yang, F.; Liu, T.; Mani, D.R.; Petyuk, V.A.; Gillette, M.A.; Clauser, K.R.; Qiao, J.W.; Gritsenko, M.A.; Moore, R.J.; et al. Ischemia in tumors induces early and sustained phosphorylation changes in stress kinase pathways but does not affect global protein levels. Mol. Cell. Proteom. 2014, 13, 1690-1704. [CrossRef]

87. Geoghegan, V.; Guo, A.; Trudgian, D.; Thomas, B.; Acuto, O. Comprehensive identification of arginine methylation in primary $\mathrm{T}$ cells reveals regulatory roles in cell signalling. Nat. Commun. 2015, 6, 6758. [CrossRef]

88. Kettenbach, A.N.; Schweppe, D.K.; Faherty, B.K.; Pechenick, D.; Pletnev, A.A.; Gerber, S.A. Quantitative phosphoproteomics identifies substrates and functional modules of Aurora and Polo-like kinase activities in mitotic cells. Sci. Signal. 2011, 4, rs5. [CrossRef]

89. Jung, S.Y.; Li, Y.; Wang, Y.; Chen, Y.; Zhao, Y.; Qin, J. Complications in the assignment of 14 and $28 \mathrm{Da}$ mass shift detected by mass spectrometry as in vivo methylation from endogenous proteins. Anal. Chem. 2008, 80, 1721-1729. [CrossRef]

90. Bergo, A.; Strollo, M.; Gai, M.; Barbiero, I.; Stefanelli, G.; Sertic, S.; Cobolli Gigli, C.; Di Cunto, F.; Kilstrup-Nielsen, C.; Landsberger, N. Methyl-CpG binding protein 2 (MeCP2) localizes at the centrosome and is required for proper mitotic spindle organization. J. Biol. Chem. 2015, 290, 3223-3237. [CrossRef]

91. D’Annessa, I.; Gandaglia, A.; Brivio, E.; Stefanelli, G.; Frasca, A.; Landsberger, N.; Di Marino, D. Tyr120Asp mutation alters domain flexibility and dynamics of MeCP2 DNA binding domain leading to impaired DNA interaction: Atomistic characterization of a Rett syndrome causing mutation. Biochim. Biophys. Acta Gen. Subj. 2018, 1862, 1180-1189. [CrossRef] [PubMed] 
92. Wagner, S.A.; Beli, P.; Weinert, B.T.; Nielsen, M.L.; Cox, J.; Mann, M.; Choudhary, C. A proteome-wide, quantitative survey of in vivo ubiquitylation sites reveals widespread regulatory roles. Mol. Cell. Proteom. 2011, 10. [CrossRef]

93. Olsen, J.V.; Vermeulen, M.; Santamaria, A.; Kumar, C.; Miller, M.L.; Jensen, L.J.; Gnad, F.; Cox, J.; Jensen, T.S.; Nigg, E.A.; et al. Quantitative phosphoproteomics reveals widespread full phosphorylation site occupancy during mitosis. Sci. Signal. 2010, 3, ra3. [CrossRef] [PubMed]

94. Guo, A.L.; Gu, H.B.; Zhou, J.; Mulhern, D.; Wang, Y.; Lee, K.A.; Yang, V.; Aguiar, M.; Kornhauser, J.; Jia, X.Y.; et al. Immunoaffinity Enrichment and Mass Spectrometry Analysis of Protein Methylation. Mol. Cell Proteom. 2014, 13, 372-387. [CrossRef] [PubMed]

95. Larsen, S.C.; Sylvestersen, K.B.; Mund, A.; Lyon, D.; Mullari, M.; Madsen, M.V.; Daniel, J.A.; Jensen, L.J.; Nielsen, M.L. Proteome-wide analysis of arginine monomethylation reveals widespread occurrence in human cells. Sci. Signal. 2016, 9, rs9. [CrossRef] [PubMed]

96. Jungmichel, S.; Rosenthal, F.; Altmeyer, M.; Lukas, J.; Hottiger, M.O.; Nielsen, M.L. Proteome-wide Identification of Poly(ADP-Ribosyl)ation Targets in Different Genotoxic Stress Responses. Mol. Cell 2013, 52, 272-285. [CrossRef] [PubMed]

97. Stefanelli, G.; Gandaglia, A.; Costa, M.; Cheema, M.S.; Di Marino, D.; Barbiero, I.; Kilstrup-Nielsen, C.; Ausio, J.; Landsberger, N. Brain phosphorylation of MeCP2 at serine 164 is developmentally regulated and globally alters its chromatin association. Sci. Rep. 2016, 6, 28295. [CrossRef] [PubMed]

98. Yi, T.; Zhai, B.; Yu, Y.; Kiyotsugu, Y.; Raschle, T.; Etzkorn, M.; Seo, H.C.; Nagiec, M.; Luna, R.E.; Reinherz, E.L.; et al. Quantitative phosphoproteomic analysis reveals system-wide signaling pathways downstream of SDF-1/CXCR4 in breast cancer stem cells. Proc. Natl. Acad. Sci. USA 2014, 111, E2182-E2190. [CrossRef]

99. Carrier, M.; Joint, M.; Lutzing, R.; Page, A.; Rochette-Egly, C. Phosphoproteome and Transcriptome of RA-Responsive and RA-Resistant Breast Cancer Cell Lines. PLoS ONE 2016, 11, e0157290. [CrossRef]

100. Lundby, A.; Lage, K.; Weinert, B.T.; Bekker-Jensen, D.B.; Secher, A.; Skovgaard, T.; Kelstrup, C.D.; Dmytriyev, A.; Choudhary, C.; Lundby, C.; et al. Proteomic analysis of lysine acetylation sites in rat tissues reveals organ specificity and subcellular patterns. Cell Rep. 2012, 2, 419-431. [CrossRef]

101. Akimov, V.; Barrio-Hernandez, I.; Hansen, S.V.F.; Hallenborg, P.; Pedersen, A.K.; Bekker-Jensen, D.B.; Puglia, M.; Christensen, S.D.K.; Vanselow, J.T.; Nielsen, M.M.; et al. UbiSite approach for comprehensive mapping of lysine and N-terminal ubiquitination sites. Nat. Struct. Mol. Biol. 2018, 25, 631-640. [CrossRef] [PubMed]

102. Cheng, J.; Huang, M.; Zhu, Y.; Xin, Y.J.; Zhao, Y.K.; Huang, J.; Yu, J.X.; Zhou, W.H.; Qiu, Z.L. SUMOylation of MeCP2 is essential for transcriptional repression and hippocampal synapse development. J. Neurochem. 2014, 128, 798-806. [CrossRef] [PubMed]

103. Chen, R.Q.; Yang, Q.K.; Lu, B.W.; Yi, W.; Cantin, G.; Chen, Y.L.; Fearns, C.; Yates, J.R., 3rd; Lee, J.D. CDC25B mediates rapamycin-induced oncogenic responses in cancer cells. Cancer Res. 2009, 69, 2663-2668. [CrossRef] [PubMed]

104. Wu, Z.; Cheng, Z.; Sun, M.; Wan, X.; Liu, P.; He, T.; Tan, M.; Zhao, Y. A chemical proteomics approach for global analysis of lysine monomethylome profiling. Mol. Cell. Proteom. 2015, 14, 329-339. [CrossRef] [PubMed]

105. Liu, F.; Ni, J.J.; Huang, J.J.; Kou, Z.W.; Sun, F.Y. VEGF overexpression enhances the accumulation of phospho-S292 MeCP2 in reactive astrocytes in the adult rat striatum following cerebral ischemia. Brain Res. 2015, 1599, 32-43. [CrossRef]

106. Parker, B.L.; Yang, G.; Humphrey, S.J.; Chaudhuri, R.; Ma, X.; Peterman, S.; James, D.E. Targeted phosphoproteomics of insulin signaling using data-independent acquisition mass spectrometry. Sci. Signal. 2015, 8, rs6. [CrossRef]

107. Beli, P.; Lukashchuk, N.; Wagner, S.A.; Weinert, B.T.; Olsen, J.V.; Baskcomb, L.; Mann, M.; Jackson, S.P.; Choudhary, C. Proteomic investigations reveal a role for RNA processing factor THRAP3 in the DNA damage response. Mol. Cell 2012, 46, 212-225. [CrossRef]

108. Weinert, B.T.; Scholz, C.; Wagner, S.A.; Iesmantavicius, V.; Su, D.; Daniel, J.A.; Choudhary, C. Lysine Succinylation Is a Frequently Occurring Modification in Prokaryotes and Eukaryotes and Extensively Overlaps with Acetylation. Cell Rep. 2013, 4, 842-851. [CrossRef]

109. Dhayalan, A.; Kudithipudi, S.; Rathert, P.; Jeltsch, A. Specificity analysis-based identification of new methylation targets of the SET7/9 protein lysine methyltransferase. Chem. Biol. 2011, 18, 111-120. [CrossRef] 
110. Wu, Q.; Cheng, Z.; Zhu, J.; Xu, W.; Peng, X.; Chen, C.; Li, W.; Wang, F.; Cao, L.; Yi, X.; et al. Suberoylanilide hydroxamic acid treatment reveals crosstalks among proteome, ubiquitylome and acetylome in non-small cell lung cancer A549 cell line. Sci. Rep. 2015, 5, 9520. [CrossRef]

111. Yang, F.; Stenoien, D.L.; Strittmatter, E.F.; Wang, J.; Ding, L.; Lipton, M.S.; Monroe, M.E.; Nicora, C.D.; Gristenko, M.A.; Tang, K.; et al. Phosphoproteome profiling of human skin fibroblast cells in response to low- and high-dose irradiation. J. Proteome Res. 2006, 5, 1252-1260. [CrossRef] [PubMed]

112. Grimsrud, P.A.; Carson, J.J.; Hebert, A.S.; Hubler, S.L.; Niemi, N.M.; Bailey, D.J.; Jochem, A.; Stapleton, D.S.; Keller, M.P.; Westphall, M.S.; et al. A Quantitative Map of the Liver Mitochondrial Phosphoproteome Reveals Posttranslational Control of Ketogenesis. Cell Metab. 2012, 16, 672-683. [CrossRef] [PubMed]

113. Deng, J.V.; Rodriguiz, R.M.; Hutchinson, A.N.; Kim, I.H.; Wetsel, W.C.; West, A.E. MeCP2 in the nucleus accumbens contributes to neural and behavioral responses to psychostimulants. Nat. Neurosci. 2010, 13, 1128-1136. [CrossRef] [PubMed]

114. Li, H.; Zhong, X.; Chau, K.F.; Williams, E.C.; Chang, Q. Loss of activity-induced phosphorylation of MeCP2 enhances synaptogenesis, LTP and spatial memory. Nat. Neurosci. 2011, 14, 1001-1008. [CrossRef] [PubMed]

115. Wang, Z.; Udeshi, N.D.; O’Malley, M.; Shabanowitz, J.; Hunt, D.F.; Hart, G.W. Enrichment and site mapping of O-linked $\mathrm{N}$-acetylglucosamine by a combination of chemical/enzymatic tagging, photochemical cleavage, and electron transfer dissociation mass spectrometry. Mol. Cell. Proteom. 2010, 9, 153-160. [CrossRef]

116. Alfaro, J.F.; Gong, C.X.; Monroe, M.E.; Aldrich, J.T.; Clauss, T.R.; Purvine, S.O.; Wang, Z.; Camp, D.G., 2nd; Shabanowitz, J.; Stanley, P.; et al. Tandem mass spectrometry identifies many mouse brain O-GlcNAcylated proteins including EGF domain-specific O-GlcNAc transferase targets. Proc. Natl. Acad. Sci. USA 2012, 109, 7280-7285. [CrossRef]

117. Trinidad, J.C.; Barkan, D.T.; Gulledge, B.F.; Thalhammer, A.; Sali, A.; Schoepfer, R.; Burlingame, A.L. Global identification and characterization of both O-GlcNAcylation and phosphorylation at the murine synapse. Mol. Cell. Proteom. 2012, 11, 215-229. [CrossRef]

118. Choudhary, C.; Kumar, C.; Gnad, F.; Nielsen, M.L.; Rehman, M.; Walther, T.C.; Olsen, J.V.; Mann, M. Lysine Acetylation Targets Protein Complexes and Co-Regulates Major Cellular Functions. Science 2009, 325, 834-840. [CrossRef]

119. Schweppe, D.K.; Rigas, J.R.; Gerber, S.A. Quantitative phosphoproteomic profiling of human non-small cell lung cancer tumors. J. Proteom. 2013, 91, 286-296. [CrossRef]

120. Chen, W.G.; Chang, Q.; Lin, Y.; Meissner, A.; West, A.E.; Griffith, E.C.; Jaenisch, R.; Greenberg, M.E. Derepression of BDNF transcription involves calcium-dependent phosphorylation of MeCP2. Science 2003, 302, 885-889. [CrossRef]

121. Martinowich, K.; Hattori, D.; Wu, H.; Fouse, S.; He, F.; Hu, Y.; Fan, G.; Sun, Y.E. DNA methylation-related chromatin remodeling in activity-dependent BDNF gene regulation. Science 2003, 302, 890-893. [CrossRef] [PubMed]

122. Song, C.; Feodorova, Y.; Guy, J.; Peichl, L.; Jost, K.L.; Kimura, H.; Cardoso, M.C.; Bird, A.; Leonhardt, H.; Joffe, B.; et al. DNA methylation reader MECP2: Cell type- and differentiation stage-specific protein distribution. Epigenetics Chromatin 2014, 7, 17. [CrossRef] [PubMed]

123. Cohen, S.; Gabel, H.W.; Hemberg, M.; Hutchinson, A.N.; Sadacca, L.A.; Ebert, D.H.; Harmin, D.A.; Greenberg, R.S.; Verdine, V.K.; Zhou, Z.L.; et al. Genome-Wide Activity-Dependent MeCP2 Phosphorylation Regulates Nervous System Development and Function. Neuron 2011, 72, 72-85. [CrossRef] [PubMed]

124. Inui, K.; Akagi, M.; Ono, J.; Tsukamoto, H.; Shimono, K.; Mano, T.; Imai, K.; Yamada, M.; Muramatsu, T.; Sakai, N.; et al. Mutational analysis of MECP2 in Japanese patients with atypical Rett syndrome. Brain Dev. 2001, 23, 212-215. [CrossRef]

125. Hagberg, B.; Aicardi, J.; Dias, K.; Ramos, O. A Progressive Syndrome of Autism, Dementia, Ataxia, and Loss of Purposeful Hand Use in Girls-Retts Syndrome-Report of 35 Cases. Ann. Neurol. 1983, 14, 471-479. [CrossRef] [PubMed]

126. Ballestar, E.; Yusufzai, T.M.; Wolffe, A.P. Effects of Rett syndrome mutations of the methyl-CpG binding domain of the transcriptional repressor $\mathrm{MeCP} 2$ on selectivity for association with methylated DNA. Biochemistry 2000, 39, 7100-7106. [CrossRef] [PubMed]

127. Yang, Y.; Kucukkal, T.G.; Li, J.; Alexov, E.; Cao, W. Binding analysis of methyl-CpG binding domain of MeCP2 and Rett syndrome mutations. ACS Chem. Biol. 2016, 11, 2706-2715. [CrossRef] 
128. Brown, K.; Selfridge, J.; Lagger, S.; Connelly, J.; De Sousa, D.; Kerr, A.; Webb, S.; Guy, J.; Merusi, C.; Koerner, M.V. The molecular basis of variable phenotypic severity among common missense mutations causing Rett syndrome. Hum. Mol. Genet. 2015, 25, 558-570. [CrossRef]

129. Venkateswaran, S.; McMillan, H.J.; Doja, A.; Humphreys, P. Adolescent onset cognitive regression and neuropsychiatric symptoms associated with the A140V MECP 2 mutation. Dev. Med. Child Neurol. 2014, 56, 91-94. [CrossRef]

130. Jentarra, G.M.; Olfers, S.L.; Rice, S.G.; Srivastava, N.; Homanics, G.E.; Blue, M.; Naidu, S.; Narayanan, V. Abnormalities of cell packing density and dendritic complexity in the MeCP2 A140V mouse model of Rett syndrome/X-linked mental retardation. BMC Neurosci. 2010, 11, 19. [CrossRef]

131. Ma, L.Y.; Wu, C.; Jin, Y.; Gao, M.; Li, G.H.; Turner, D.; Shen, J.X.; Zhang, S.J.; Narayanan, V.; Jentarra, G. Electrophysiological Phenotypes of Me CP 2 A140V Mutant Mouse Model. CNS Neurosci. Ther. 2014, 20, 420-428. [CrossRef] [PubMed]

132. Sampathkumar, R.; Shannon, O.; Brittany, G.; Hilbert, A.; Sean, S.; Vinodh, N. Reduced neuronal size and mTOR pathway activity in the Mecp2 A140V Rett syndrome mouse model. F1000Research 2016, 5, 2269. [CrossRef]

133. Lundvall, M.; Samuelsson, L.; Kyllerman, M. Male Rett phenotypes in T158M and R294X MeCP2-mutations. Neuropediatrics 2006, 37, 296-301. [CrossRef] [PubMed]

134. Olson, C.O.; Pejhan, S.; Kroft, D.; Sheikholeslami, K.; Fuss, D.; Buist, M.; Sher, A.A.; Del Bigio, M.R.; Sztainberg, Y.; Siu, V.M. MECP2 Mutation Interrupts Nucleolin-mTOR-P70S6K Signaling in Rett Syndrome Patients. Front. Genet. 2018, 9, 635. [CrossRef] [PubMed]

135. Bu, Q.; Wang, A.; Hamzah, H.; Waldman, A.; Jiang, K.; Dong, Q.; Li, R.; Kim, J.; Turner, D.; Chang, Q. CREB signaling is involved in Rett syndrome pathogenesis. J. Neurosci. 2017, 37, 3671-3685. [CrossRef] [PubMed]

136. Chapleau, C.A.; Calfa, G.D.; Lane, M.C.; Albertson, A.J.; Larimore, J.L.; Kudo, S.; Armstrong, D.L.; Percy, A.K.; Pozzo-Miller, L. Dendritic spine pathologies in hippocampal pyramidal neurons from Rett syndrome brain and after expression of Rett-associated MECP2 mutations. Neurobiol. Dis. 2009, 35, 219-233. [CrossRef]

137. Lawson-Yuen, A.; Liu, D.; Han, L.; Jiang, Z.I.; Tsai, G.E.; Basu, A.C.; Picker, J.; Feng, J.; Coyle, J.T. Ube3a mRNA and protein expression are not decreased in Mecp2R168X mutant mice. Brain Res. 2007, 1180, 1-6. [CrossRef]

138. Schaevitz, L.; Gomez, N.; Zhen, D.; Berger-Sweeney, J. MeCP2 R168X male and female mutant mice exhibit Rett-like behavioral deficits. Genes Brain Behav. 2013, 12, 732-740. [CrossRef]

139. Bissonnette, J.M.; Schaevitz, L.R.; Knopp, S.J.; Zhou, Z. Respiratory phenotypes are distinctly affected in mice with common Rett syndrome mutations MeCP2 T158A and R168X. Neuroscience 2014, 267, 166-176. [CrossRef]

140. Georgel, P.T.; Horowitz-Scherer, R.A.; Adkins, N.; Woodcock, C.L.; Wade, P.A.; Hansen, J.C. Chromatin compaction by human MeCP2 assembly of novel secondary chromatin structures in the absence of DNA methylation. J. Biol. Chem. 2003, 278, 32181-32188. [CrossRef] [PubMed]

141. Yusufzai, T.M.; Wolffe, A.P. Functional consequences of Rett syndrome mutations on human MeCP2. Nucleic Acids Res. 2000, 28, 4172-4179. [CrossRef] [PubMed]

142. Pitcher, M.R.; Herrera, J.A.; Buffington, S.A.; Kochukov, M.Y.; Merritt, J.K.; Fisher, A.R.; Schanen, N.C.; Costa-Mattioli, M.; Neul, J.L. Rett syndrome like phenotypes in the R255X Mecp2 mutant mouse are rescued by MECP2 transgene. Hum. Mol. Genet. 2015, 24, 2662-2672. [CrossRef] [PubMed]

143. Villard, L. MECP2 mutations in males. J. Med. Genet. 2007, 44, 417-423. [CrossRef]

144. Baker, S.A.; Chen, L.; Wilkins, A.D.; Yu, P.; Lichtarge, O.; Zoghbi, H.Y. An AT-hook domain in MeCP2 determines the clinical course of Rett syndrome and related disorders. Cell 2013, 152, 984-996. [CrossRef] [PubMed]

145. Goffin, D.; Allen, M.; Zhang, L.; Amorim, M.; Wang, I.-T.J.; Reyes, A.-R.S.; Mercado-Berton, A.; Ong, C.; Cohen, S.; Hu, L. Rett syndrome mutation MeCP2 T158A disrupts DNA binding, protein stability and ERP responses. Nat. Neurosci. 2012, 15, 274. [CrossRef] [PubMed]

146. Tillotson, R.; Bird, A. The Molecular Basis of MeCP2 Function in the Brain. J. Mol. Biol. 2019, 432, 1602-1623. [CrossRef]

147. Heckman, L.D.; Chahrour, M.H.; Zoghbi, H.Y. Rett-causing mutations reveal two domains critical for MeCP2 function and for toxicity in MECP2 duplication syndrome mice. eLife 2014, 3, e02676. [CrossRef] 
148. Ravn, K.; Nielsen, J.; Uldall, P.; Hansen, F.; Schwartz, M. No correlation between phenotype and genotype in boys with a truncating MECP2 mutation. J. Med. Genet. 2003, 40, e5. [CrossRef]

149. Galvao, T.C.; Thomas, J.O. Structure-specific binding of MeCP2 to four-way junction DNA through its methyl CpG-binding domain. Nucleic Acids Res. 2005, 33, 6603-6609. [CrossRef]

150. Horike, S.; Cai, S.; Miyano, M.; Cheng, J.F.; Kohwi-Shigematsu, T. Loss of silent-chromatin looping and impaired imprinting of DLX5 in Rett syndrome. Nat. Genet. 2005, 37, 31-40. [CrossRef]

151. Fudenberg, G.; Imakaev, M.; Lu, C.; Goloborodko, A.; Abdennur, N.; Mirny, L.A. Formation of chromosomal domains by loop extrusion. Cell Rep. 2016, 15, 2038-2049. [CrossRef] [PubMed]

152. Sanborn, A.L.; Rao, S.S.; Huang, S.-C.; Durand, N.C.; Huntley, M.H.; Jewett, A.I.; Bochkov, I.D.; Chinnappan, D.; Cutkosky, A.; Li, J. Chromatin extrusion explains key features of loop and domain formation in wild-type and engineered genomes. Proc. Natl. Acad. Sci. USA 2015, 112, E6456-E6465. [CrossRef] [PubMed]

153. Kernohan, K.D.; Vernimmen, D.; Gloor, G.B.; Berube, N.G. Analysis of neonatal brain lacking ATRX or MeCP2 reveals changes in nucleosome density, CTCF binding and chromatin looping. Nucleic Acids Res. 2014, 42, 8356-8368. [CrossRef] [PubMed]

154. Murrell, A.; Heeson, S.; Reik, W. Interaction between differentially methylated regions partitions the imprinted genes Igf2 and H19 into parent-specific chromatin loops. Nat. Genet. 2004, 36, 889-893. [CrossRef] [PubMed]

155. Nativio, R.; Wendt, K.S.; Ito, Y.; Huddleston, J.E.; Uribe-Lewis, S.; Woodfine, K.; Krueger, C.; Reik, W.; Peters, J.-M.; Murrell, A. Cohesin is required for higher-order chromatin conformation at the imprinted IGF2-H19 locus. PLoS Genet. 2009, 5, e1000739. [CrossRef] [PubMed]

156. Bell, A.C.; Felsenfeld, G. Methylation of a CTCF-dependent boundary controls imprinted expression of the Igf2 gene. Nature 2000, 405, 482-485. [CrossRef]

157. Hark, A.T.; Schoenherr, C.J.; Katz, D.J.; Ingram, R.S.; Levorse, J.M.; Tilghman, S.M. CTCF mediates methylation-sensitive enhancer-blocking activity at the H19/Igf2 locus. Nature 2000, 405, 486-489. [CrossRef] [PubMed]

158. Wang, H.; Maurano, M.T.; Qu, H.Z.; Varley, K.E.; Gertz, J.; Pauli, F.; Lee, K.; Canfield, T.; Weaver, M.; Sandstrom, R.; et al. Widespread plasticity in CTCF occupancy linked to DNA methylation. Genome Res. 2012, 22, 1680-1688. [CrossRef]

159. Witcher, M.; Emerson, B.M. Epigenetic Silencing of the p16(INK4a) Tumor Suppressor Is Associated with Loss of CTCF Binding and a Chromatin Boundary. Mol. Cell 2009, 34, 271-284. [CrossRef]

160. Soto-Reyes, E.; Recillas-Targa, F. Epigenetic regulation of the human p53 gene promoter by the CTCF transcription factor in transformed cell lines. Oncogene 2010, 29, 2217-2227. [CrossRef]

161. Marina, R.J.; Sturgill, D.; Bailly, M.A.; Thenoz, M.; Varma, G.; Prigge, M.F.; Nanan, K.K.; Shukla, S.; Haque, N.; Oberdoerffer, S. TET-catalyzed oxidation of intragenic 5-methylcytosine regulates CTCF-dependent alternative splicing. EMBO J. 2016, 35, 335-355. [CrossRef] [PubMed]

162. Nanan, K.K.; Sturgill, D.M.; Prigge, M.F.; Thenoz, M.; Dillman, A.A.; Mandler, M.D.; Oberdoerffer, S. TET-catalyzed 5-carboxylcytosine promotes CTCF binding to suboptimal sequences genome-wide. iScience 2019, 19, 326-339. [CrossRef] [PubMed]

163. He, Y.F.; Li, B.Z.; Li, Z.; Liu, P.; Wang, Y.; Tang, Q.; Ding, J.; Jia, Y.; Chen, Z.; Li, L.; et al. Tet-mediated formation of 5-carboxylcytosine and its excision by TDG in mammalian DNA. Science 2011, 333, 1303-1307. [CrossRef] [PubMed]

164. Barutcu, A.R.; Lian, J.B.; Stein, J.L.; Stein, G.S.; Imbalzano, A.N. The connection between BRG1, CTCF and topoisomerases at TAD boundaries. Nucleus 2017, 8, 150-155. [CrossRef]

165. Pearson, E.C.; Bates, D.L.; Prospero, T.D.; Thomas, J.O. Neuronal nuclei and glial nuclei from mammalian cerebral cortex: Nucleosome repeat lengths, DNA contents and H1 contents. Eur. J. Biochem. 1984, 144, 353-360. [CrossRef]

166. Ghosh, R.P.; Horowitz-Scherer, R.A.; Nikitina, T.; Shlyakhtenko, L.S.; Woodcock, C.L. MeCP2 binds cooperatively to its substrate and competes with histone $\mathrm{H} 1$ for chromatin binding sites. Mol. Cell. Biol. 2010, 30, 4656-4670. [CrossRef] 
167. Kumar, A.; Kamboj, S.; Malone, B.M.; Kudo, S.; Twiss, J.L.; Czymmek, K.J.; LaSalle, J.M.; Schanen, N.C. Analysis of protein domains and Rett syndrome mutations indicate that multiple regions influence chromatin-binding dynamics of the chromatin-associated protein MECP2 in vivo. J. Cell Sci. 2008, 121, 1128-1137. [CrossRef]

168. Misteli, T.; Gunjan, A.; Hock, R.; Bustin, M.; Brown, D.T. Dynamic binding of histone H1 to chromatin in living cells. Nature 2000, 408, 877. [CrossRef]

169. Nan, X.; Campoy, F.J.; Bird, A. MeCP2 is a transcriptional repressor with abundant binding sites in genomic chromatin. Cell 1997, 88, 471-481. [CrossRef]

170. Wang, C.; Wang, F.; Li, Z.; Cao, Q.; Huang, L.; Chen, S. MeCP2-mediated epigenetic regulation in senescent endothelial progenitor cells. Stem Cell Res. Ther. 2018, 9, 87. [CrossRef]

171. Pandey, S.; Simmons, G.E., Jr.; Malyarchuk, S.; Calhoun, T.N.; Pruitt, K. A novel MeCP2 acetylation site regulates interaction with ATRX and HDAC1. Genes Cancer 2015, 6, 408-421. [CrossRef] [PubMed]

172. Mitchell, A.R. The mammalian centromere: Its molecular architecture. Mutat. Res./Fundam. Mol. Mech. Mutagenesis 1996, 372, 153-162. [CrossRef]

173. Baccarini, P. Sulle Cinesi Vegetative del Cynomorium coccineum L. N Giorn Bot. Ital. N Ser. 1908, 15, $189-203$.

174. Brero, A.; Easwaran, H.P.; Nowak, D.; Grunewald, I.; Cremer, T.; Leonhardt, H.; Cardoso, M.C. Methyl CpG-binding proteins induce large-scale chromatin reorganization during terminal differentiation. J. Cell Biol. 2005, 169, 733-743. [CrossRef] [PubMed]

175. Bertulat, B.; De Bonis, M.L.; Della Ragione, F.; Lehmkuhl, A.; Milden, M.; Storm, C.; Jost, K.L.; Scala, S.; Hendrich, B.; D'Esposito, M. MeCP2 dependent heterochromatin reorganization during neural differentiation of a novel Mecp2-deficient embryonic stem cell reporter line. PLoS ONE 2012, 7, e47848. [CrossRef] [PubMed]

176. Nikitina, T.; Ghosh, R.P.; Horowitz-Scherer, R.A.; Hansen, J.C.; Grigoryev, S.A.; Woodcock, C.L. $\mathrm{MeCP} 2$-chromatin interactions include the formation of chromatosome-like structures and are altered in mutations causing Rett syndrome. J. Biol. Chem. 2007, 282, 28237-28245. [CrossRef] [PubMed]

177. Protter, D.S.; Parker, R. Principles and properties of stress granules. Trends Cell Biol. 2016, 26, 668-679. [CrossRef]

178. Shaw, P.; Brown, J. Nucleoli: Composition, function, and dynamics. Plant Physiol. 2012, 158, 44-51. [CrossRef]

179. Brangwynne, C.P.; Eckmann, C.R.; Courson, D.S.; Rybarska, A.; Hoege, C.; Gharakhani, J.; Jülicher, F.; Hyman, A.A. Germline P granules are liquid droplets that localize by controlled dissolution/condensation. Science 2009, 324, 1729-1732. [CrossRef]

180. Boeynaems, S.; Alberti, S.; Fawzi, N.L.; Mittag, T.; Polymenidou, M.; Rousseau, F.; Schymkowitz, J.; Shorter, J.; Wolozin, B.; Van Den Bosch, L. Protein phase separation: A new phase in cell biology. Trends Cell Biol. 2018, 28, 420-435. [CrossRef]

181. Oldfield, C.J.; Dunker, A.K. Intrinsically disordered proteins and intrinsically disordered protein regions. Annu. Rev. Biochem. 2014, 83, 553-584. [CrossRef] [PubMed]

182. Li, P.; Banjade, S.; Cheng, H.-C.; Kim, S.; Chen, B.; Guo, L.; Llaguno, M.; Hollingsworth, J.V.; King, D.S.; Banani, S.F. Phase transitions in the assembly of multivalent signalling proteins. Nature 2012, 483, 336-340. [CrossRef] [PubMed]

183. Molliex, A.; Temirov, J.; Lee, J.; Coughlin, M.; Kanagaraj, A.P.; Kim, H.J.; Mittag, T.; Taylor, J.P. Phase separation by low complexity domains promotes stress granule assembly and drives pathological fibrillization. Cell 2015, 163, 123-133. [CrossRef] [PubMed]

184. Brangwynne, C.P.; Tompa, P.; Pappu, R.V. Polymer physics of intracellular phase transitions. Nat. Phys. 2015, 11, 899-904. [CrossRef]

185. Dubochet, J.; Adrian, M.; Schultz, P.; Oudet, P. Cryo-electron microscopy of vitrified SV40 minichromosomes: The liquid drop model. EMBO J. 1986, 5, 519-528. [CrossRef] [PubMed]

186. Maeshima, K.; Rogge, R.; Tamura, S.; Joti, Y.; Hikima, T.; Szerlong, H.; Krause, C.; Herman, J.; Seidel, E.; DeLuca, J. Nucleosomal arrays self-assemble into supramolecular globular structures lacking 30-nm fibers. EMBO J. 2016, 35, 1115-1132. [CrossRef]

187. Gibson, B.A.; Doolittle, L.K.; Schneider, M.W.; Jensen, L.E.; Gamarra, N.; Henry, L.; Gerlich, D.W.; Redding, S.; Rosen, M.K. Organization of chromatin by intrinsic and regulated phase separation. Cell 2019, 179, 470-484.e421. [CrossRef] 
188. Strom, A.R.; Emelyanov, A.V.; Mir, M.; Fyodorov, D.V.; Darzacq, X.; Karpen, G.H. Phase separation drives heterochromatin domain formation. Nature 2017, 547, 241245. [CrossRef]

189. Larson, A.G.; Elnatan, D.; Keenen, M.M.; Trnka, M.J.; Johnston, J.B.; Burlingame, A.L.; Agard, D.A.; Redding, S.; Narlikar, G.J. Liquid droplet formation by HP1 $\alpha$ suggests a role for phase separation in heterochromatin. Nature 2017, 547, 236-240. [CrossRef] 